\title{
Compositional variations of chromiferous spinel in Mg-rich rocks of the Deccan Traps, India
}

\author{
Leone Melluso ${ }^{1, *}$, Roberto de' Gennaro ${ }^{2}$ and Ivana Rocco ${ }^{1}$ \\ ${ }^{1}$ Dipartimento di Scienze della Terra Università di Napoli Federico II, via Mezzocannone 8, 80134 Napoli, Italy. \\ ${ }^{2}$ Centro Interdipartimentale Strumentazioni per Analisi Geomineralogiche (C.I.S.A.G.), Università di Napoli \\ Federico II, via Mezzocannone 8, 80134 Napoli, Italy. \\ *e-mail:melluso@unina.it
}

Composition of chromiferous spinel included in olivines of Mg-rich basalts and gabbros of the Deccan Traps (Gujarat and Western Ghats) are reported here. They vary from Al-rich compositions $\left[\mathrm{Al}_{2} \mathrm{O}_{3}=53\right.$ wt. $\left.\% ; \mathrm{Cr} \#, 100 \mathrm{Cr} /(\mathrm{Cr}+\mathrm{Al})=12\right]$ to Cr-rich compositions $\left[\mathrm{Cr}_{2} \mathrm{O}_{3}=51 \mathrm{wt} . \%\right.$; $\mathrm{Cr} \#=84]$, and from $\mathrm{Cr}-\mathrm{Al}$ rich compositions towards Cr-rich Ti-magnetite $\left(\mathrm{TiO}_{2}\right.$ up to $23 \mathrm{wt} . \%$, ulvöspinel up to $67 \mathrm{~mol} . \%)$. The $\mathrm{Mg} \#\left[100 \mathrm{Mg} /\left(\mathrm{Mg}+\mathrm{Fe}^{2+}\right)\right]$ of spinel decreases from 81 to nearly zero. The highest Cr\# has been found in the Bushe Fm., Thakurvadi Fm., and some high-Ti basalts of the Pavagadh section, whereas some of the low-Ti basalts of Saurashtra have Al-rich compositions typical of spinels found in mid-ocean ridge basalts. The chemical composition of the Deccan Trap spinels is completely different compared to that observed in mantle spinel suites, with very few exceptions. The decreasing $\mathrm{Al}$ and increasing $\mathrm{Fe}$ and $\mathrm{Ti}$ of spinel seems to be mainly the result of decrease of $\mathrm{Mg}$ in the locally coexisting melts and favourable cationic substitutions in the lattice. There is barely any evidence of general relationships between the composition of the Deccan spinels and inferred mantle sources of the host magmas. Pyroxene inclusions in spinels may witness a high-pressure stage of crystallization, but the possibility of non-equilibrium crystallization, or even magma mixing, cannot be ruled out. Overall, the compositional ranges of chromiferous spinel in the Deccan Traps closely match those observed in the other Large Igneous Provinces having mafic/ultramafic intrusions and mafic magma compositions (e.g., Siberian Traps, Karoo, Emeishan).

\section{Introduction}

Chromiferous spinel is one of the liquidus phases of primitive basaltic magmas at crustal (or shallow mantle) pressure, along with olivine. Despite being an accessory phase during crystallization (roughly 100 olivine to 1 spinel; Roeder et al 2006), its variations in chemistry may have significant petrogenetic inferences, bearing information about the composition of the source region of the magmas (Dick and Bullen 1984; Arai 1994), evolution processes (Barnes and Roeder 2001), parameters such as oxygen fugacity and temperature (Allan et al 1988). Chromiferous spinel is also known to be associated to Platinum group elements (PGE) mineralization, or is thought to be a potential host or catalyst for PGE-rich minerals (Finnigan et al 2008).

Spinel is a common alteration-resistant detritic mineral in sedimentary sequences, and is used as indicator of the tectonic setting of formation (Lee 1999; Kamenetsky et al 2001; Zhu et al 2004), even though, the spinel compositions crystallized in different tectonic settings could have considerable overlap, due to the limited cationic substitutions allowed in this mineral. It is therefore interesting to have better knowledge of the composition of this mineral in a Large Igneous Province

Keywords. Chromiferous spinel; pyroxene inclusions; Large Igneous Provinces; Deccan Traps; India. 

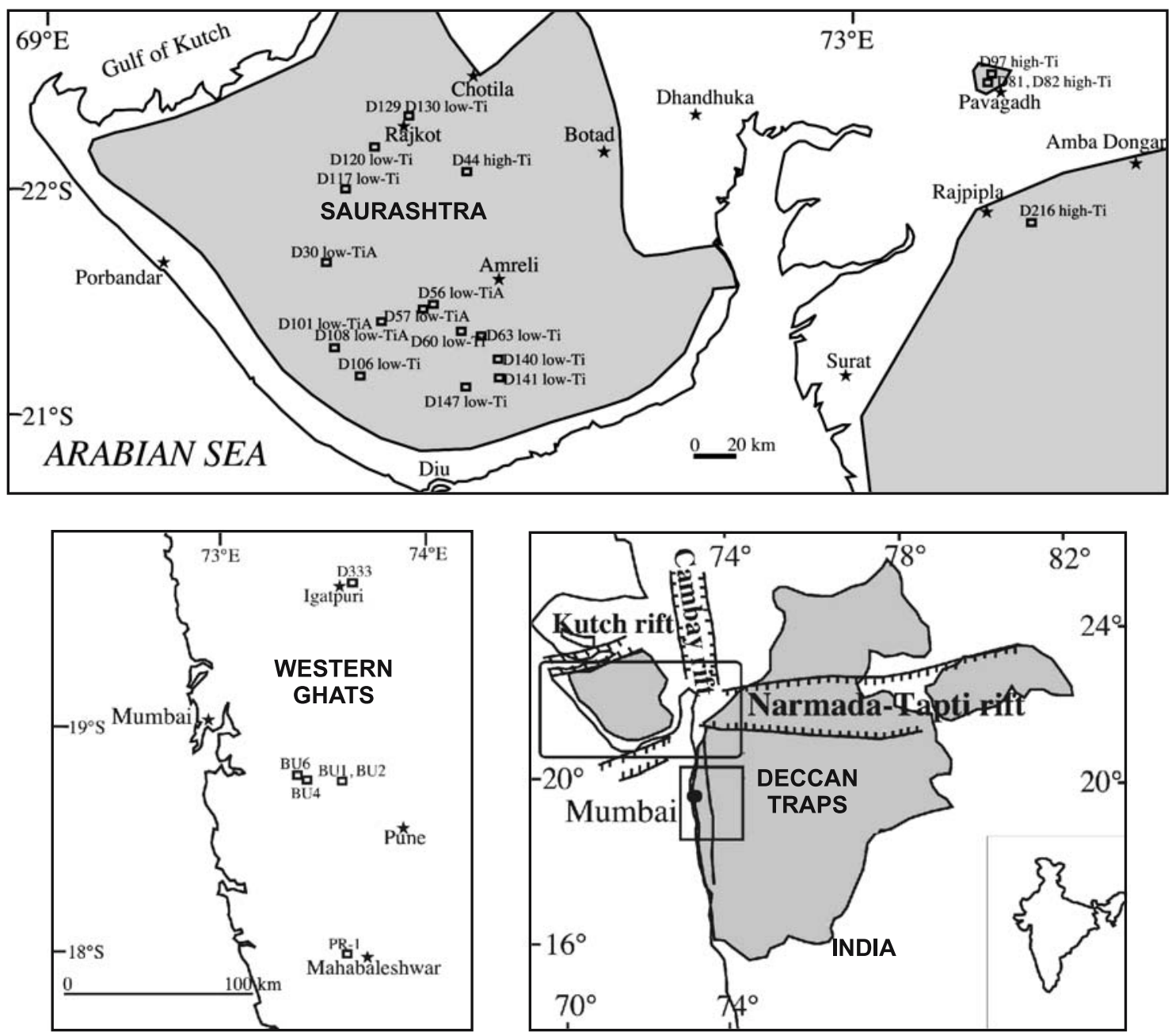

Figure 1. The Deccan Traps and location of Mg-rich samples reported in table 1.

such as the Deccan Traps of western India, given that the age of this igneous event is slightly earlier to, or coeval with, the Cretaceous-Tertiary boundary. Moreover, materials rich in chromiferous spinels are widespread in the detritic successions of Arabian Sea and Bay of Bengal and may derive from dismantling the Deccan successions (Najman et al 2008).

Studies of the composition of chromiferous spinel in typical Large Igneous Provinces (LIPs), mafic intrusions or ophiolites are numerous (Eales and Snowden 1979; Cawthorn and Biggar 1993; Barnes and Kunilov 2000; Barnes and Roeder 2001; Garuti et al 2003; Wang et al 2005, 2008; Melluso et al $2005,2006 \mathrm{~b})$. In the specific case, details on the chemistry of spinels in the volcanic rocks of the Deccan Traps are unusually scarce (Krishnamurthy and Cox 1977; Melluso et al 1995; Furuyama et al 2001). More frequent reports about other Deccan Fe-Ti oxides (magnetite, ilmenite and pseudobrookite) are found (e.g., Murari et al 1993; Ahmad and Shrivastava 2004). Therefore, the scope of this paper is a report of the composition of chromiferous spinel in Deccan Traps primitive basalts, to point out the chemical variations of this phase in the Deccan rocks and early crystallization processes which caused crystallization of spinel in primitive Deccan magmas.

\section{Geological and petrological background}

The Deccan Traps, one of the largest continental LIPs, crop out in western India, with minor outcrops in the Seychelles Islands (Mahoney 1988; Devey and Stephens 1992) (figure 1). The extent of the province offshore is not well established (Collier et al 2008 and references therein). The age of this volcanic province is instead well known to have a peak at ca. 67-65 Ma (Chenet et al 2007 and references therein), thus virtually coincident with the Cretaceous-Cenozoic (K/T) boundary (65.5 Ma, Gradstein et al 2004). The genesis of the Deccan Traps is generally linked to the massive impact of La Réunion hotspot beneath the Indian lithosphere (e.g., Mahoney et al 2002, see also Sheth 2005). 

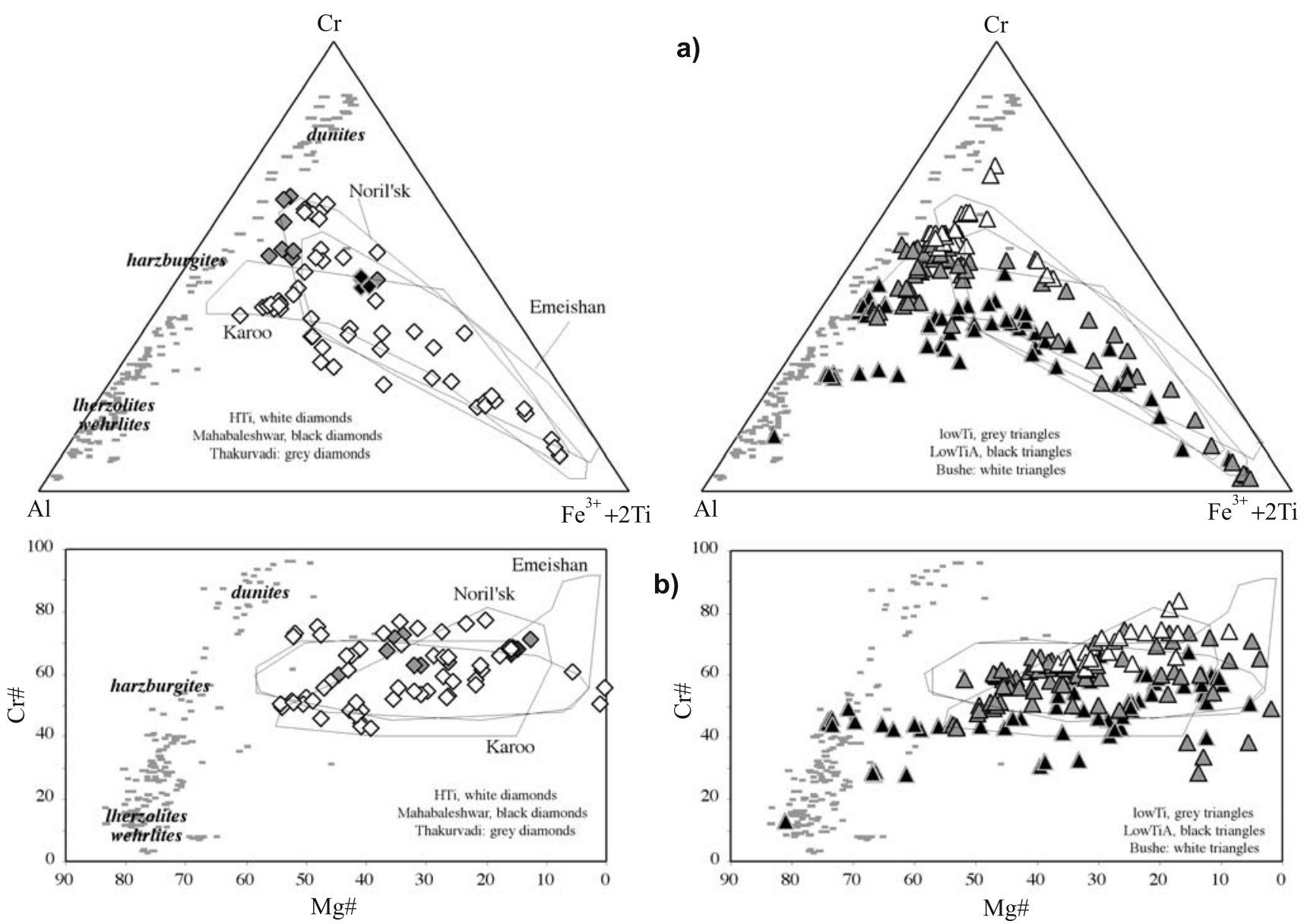

Figure 2. $\mathrm{Cr}-\mathrm{Al}-\mathrm{Fe}^{3+}+2 \mathrm{Ti}$ (a) and $\mathrm{Cr} \#-\mathrm{Mg} \#$ (b) diagrams (cations in apfu, on the basis of 32 oxygen anions). The diagrams have been splitted to avoid overcrowding. The similarities of the Deccan spinels with mantle spinels, particularly for the ranges of $\mathrm{Cr}$ and $\mathrm{Al}$, readily disappear when also $\mathrm{Mg} \#$ is considered. A few mantle spinel suites (small grey lines) are also plotted for comparison: they come from the available and nearest mantle sections of the Deccan Traps, as representatives of a 'baseline': the mantle-derived spinel lherzolites of Kutch (Krishnamurthy et al 1988, 1999; Mukherjee and Biswas 1988; Sen et al 2009) as representatives of sub-Deccan lithospheric mantle; the spinel suites of lithospheric mantle xenoliths (lherzolites and harzburgites) enclosed in Late Cenozoic alkali basalts and basanites of northernmost Madagascar (I Rocco and L Melluso, unpublished data), as representative of a lithospheric mantle section strictly contiguous to that beneath western India, at least until the late Mesozoic; the spinel suite of Central Indian Ridge abyssal peridotites (Hellebrand et al 2002); the spinel suite in Ubekendt Ejland (east Greenland) harzburgite and dunite xenoliths, as an example of spinel in very highly melt-depleted mantle (likely as much as $40 \%$ partial melts; e.g., Bernstein et al 2006). The fields indicate the range of chromiferous spinel compositions in Siberian Trap intrusions (Barnes and Kunilov 2000), Emeishan intrusions (Wang et al 2005, 2008) and Karoo (Eales and Snowden 1979).

Rocks of the Deccan Trap show geochemical and isotopic variations related to fractional crystallization of olivine, plagioclase and clinopyroxene, coupled with large-scale crustal assimilation processes during the rise of the magmas to the surface (Lightfoot et al 1990; Peng et al 1994 and see below). This is also accompanied by geochemical and isotopic heterogeneity of the mantle involved in the petrogenesis of the Deccan magmas (Melluso et al 2006a). The Deccan Traps are not a province rich in primitive, mantle-derived magmas (cf. Mahoney 1988). Indeed, by far, most of the erupted compositions are Mg-poor basalts, ferrobasalts and basaltic andesites, with minor amounts of dacites, trachytes and rhyolites (Beane et al 1986; Mahoney 1988; Subbarao and Hooper 1988; Peng et al 1994, 1998; Melluso et al 1995, 2004; Mahoney et al 2000; Sheth and Melluso 2008). Nonetheless, outcrops of Mg-rich lavas and dykes, though scarce, are known in the Western Ghats (Cox and Hawkesworth 1985; Beane and Hooper 1988), and in Gujarat (Krishnamurthy and Cox 1977; Melluso et al 1995, 2006a).

The data of table 2 have been subdivided taking into account the chemical affinity of the samples already established in previous papers (all information can be found in Subbarao and Hooper 1988; Lightfoot et al 1990; Melluso et al 1995, 2004, 2006a). The low-Ti picritic tholeiitic basalts of Saurashtra are distinguished from the 

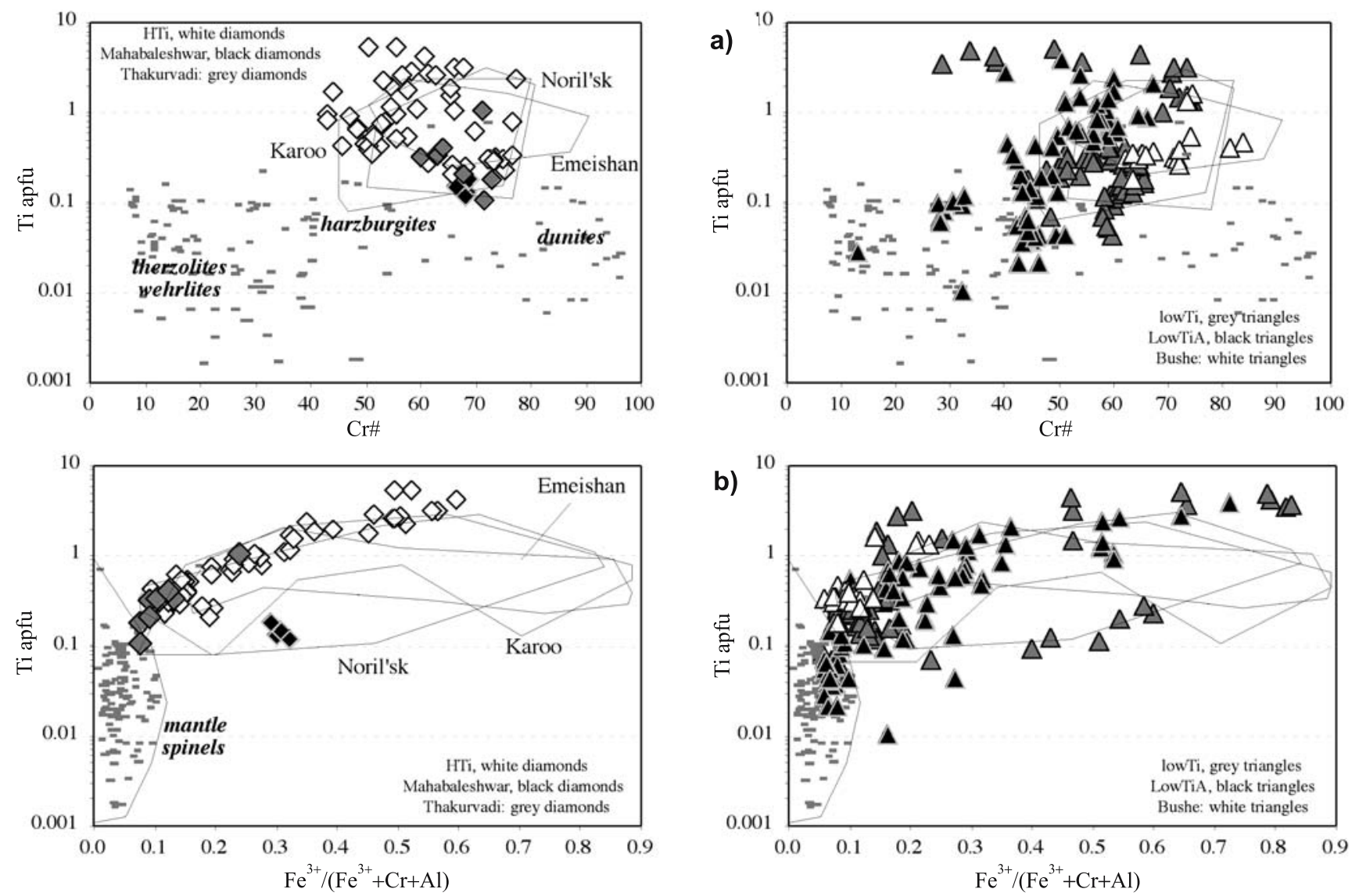

Figure 3. (a) Cr\#-Ti (apfu) diagram and (b) Fe\# vs. Ti (apfu) diagram. The diagrams are splitted to avoid overcrowding. The Deccan spinels plot outside a typical mantle field, with the exception of a few spinel analyses of low-Ti and low-TiA suites. The magmatic spinels overlap in the area with Ti apfu $>0.2$, regardless of their magmatic affinity. The mantle spinel suites are the same as in figure 2 .

weakly alkaline (hereafter low-TiA) analogues on the basis of the presence of augite (-ferroaugite) and pigeonite in the former, and Ti-rich diopside (-hedenbergite) clinopyroxene in the latter (Melluso et al 1995; Melluso and Sethna 2010). Both types are incompatible-element-depleted basalts, with a trough at $\mathrm{Nb}$, and sometimes $\mathrm{Ti}$, in primitive mantle-normalized incompatible element diagrams. These features have been interpreted as due to crustal contamination or a very small amount of a crustal component in a meltdepleted source mantle (Melluso et al 2006a). The high-Ti picritic basalts of Gujarat are the most incompatible element-enriched magma types in the Deccan lava pile (Peng and Mahoney 1995; Melluso et al 2006a; Sheth and Melluso 2008). A significant dataset has been obtained on the spinels of the Bushe Fm. lavas cropping out extensively between Pune and Mumbai (figure 1). The lavas of this formation are well known to be strongly contaminated by the Indian basement, have the highest ${ }^{87} \mathrm{Sr} /{ }^{86} \mathrm{Sr}$ among all the Deccan rocks (initial ${ }^{87} \mathrm{Sr} /{ }^{86} \mathrm{Sr}$ up to 0.720; Peng et al 1994), coupled with low contents of $\mathrm{Nb}$ and $\mathrm{TiO}_{2}$ (Cox and Hawkesworth 1985;
Peng et al 1994). The lava of the Thakurvadi Fm. at Igatpuri (D333) has a mantle-normalized incompatible element pattern characterized by marked $\mathrm{Nb}$ and $\mathrm{Ti}$ troughs (Melluso et al 2004). The Mahableshwar Fm. sample (PR-1) at the Pratapgadh Fort, about $8 \mathrm{~km}$ west of the Mahabaleshwar town (figure 1), is a likely correlative of the Kelghar mafic unit found in the Mahabaleshwar section in the east (Cox and Hawkesworth 1985).

The host rocks were sampled in the Saurashtra peninsula, the Pavagadh and Rajpipla/Narmada sections, and the Western Ghats (figure 1). They have $\mathrm{MgO}$ content in a range between $27 \mathrm{wt} . \%$ (picritic gabbro BU6), and 9 wt.\% (low-Ti basalt D63). The Ni contents vary from 770 to $118 \mathrm{ppm}$ and Cr from 1060 to $360 \mathrm{ppm}$ (table 1).

\section{Analytical techniques}

We use in this paper 230 analyses of idiomorphic to rounded spinel included in olivine (or, rarely, in plagioclase and clinopyroxene) in twenty-four samples (tables 1 and 2). Chromiferous spinels of 


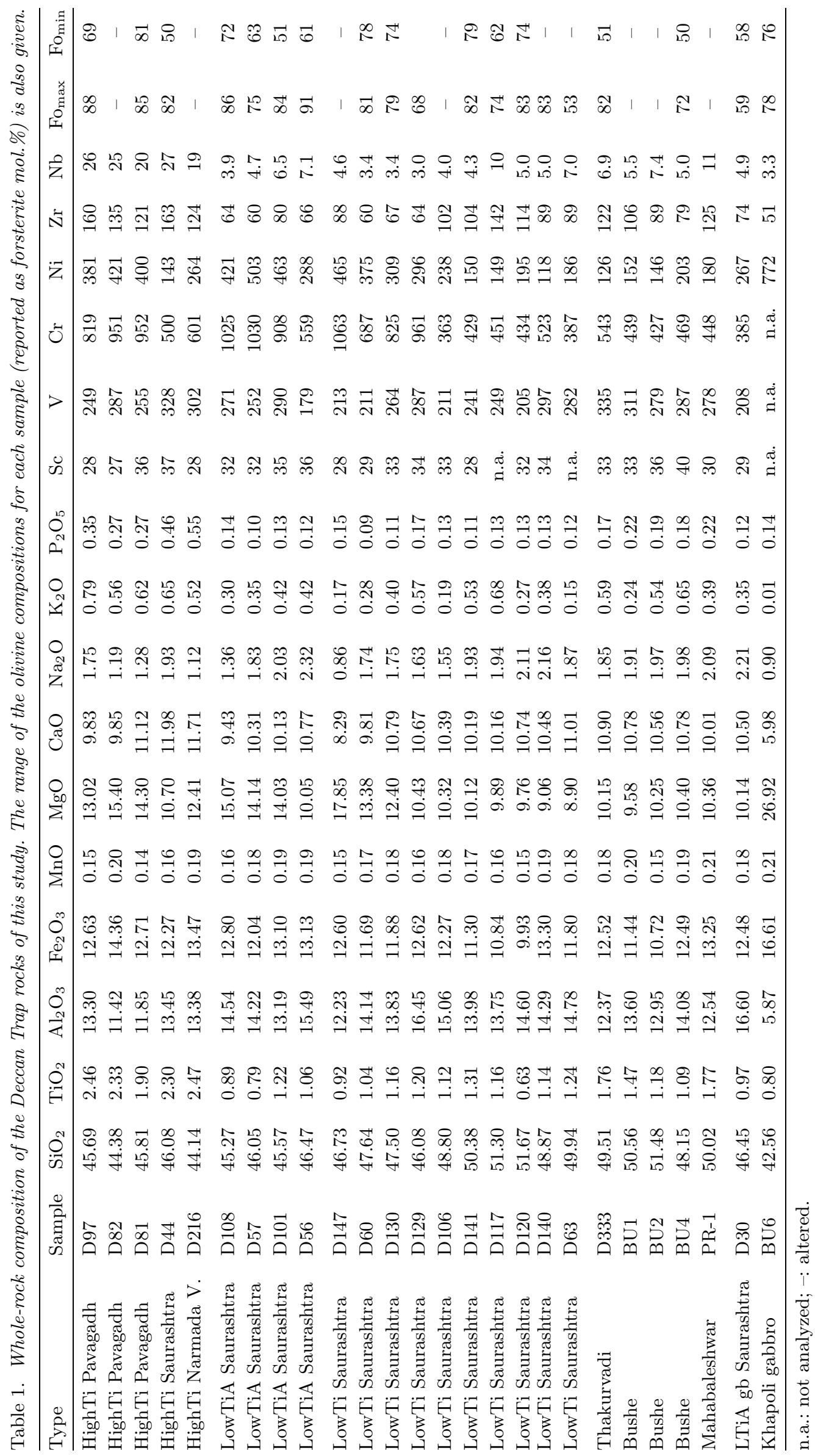




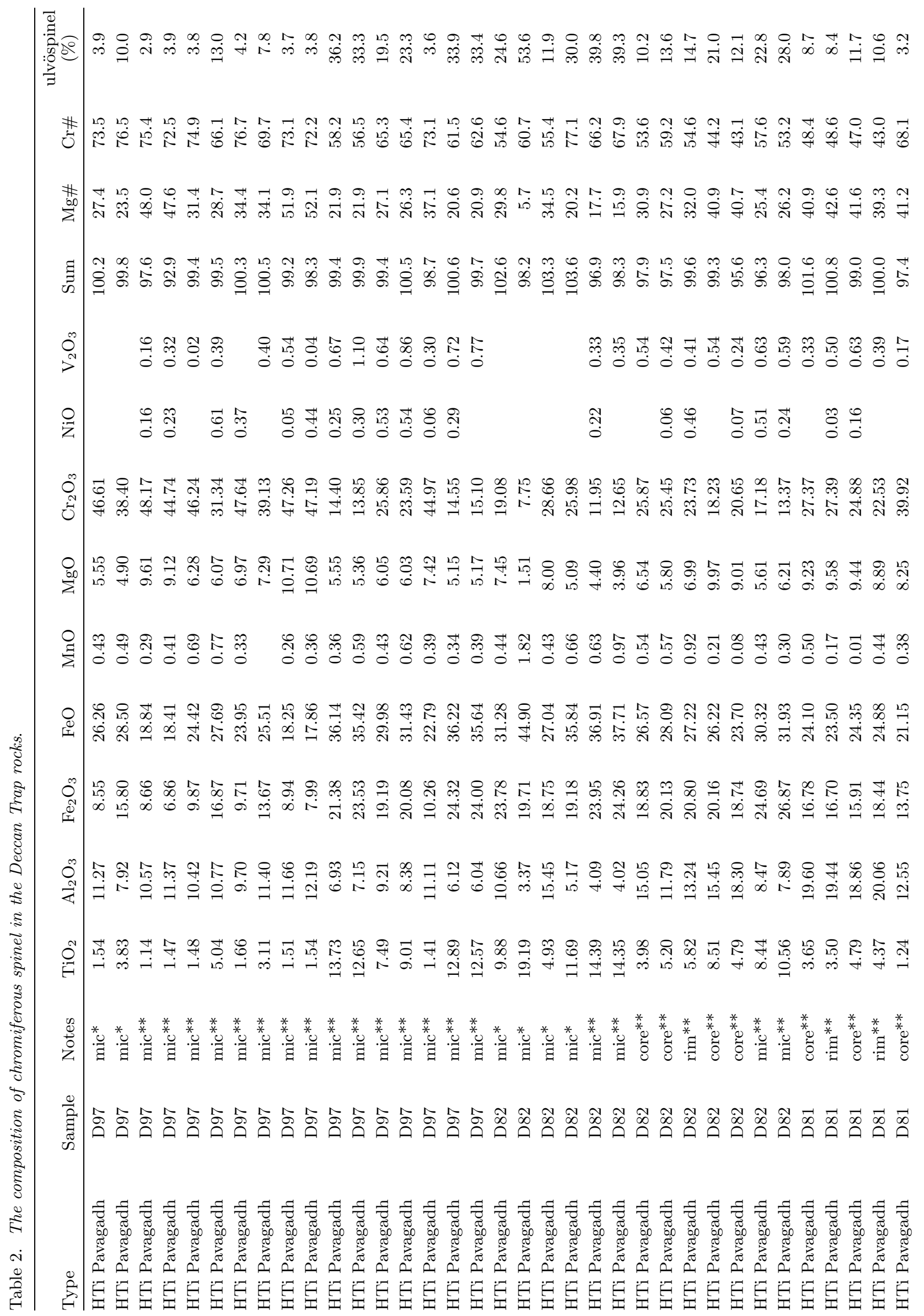


म斤

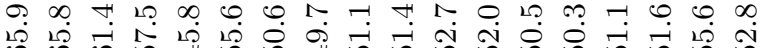

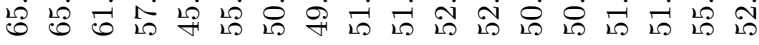

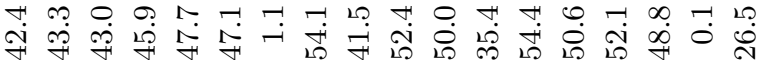

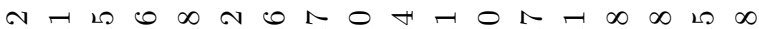

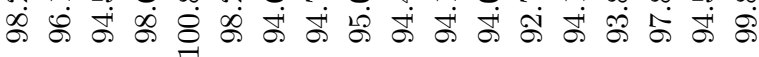

ำ ำ ㅇำ

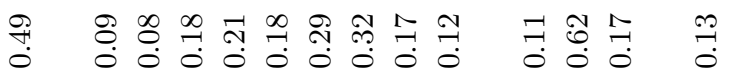

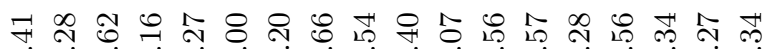

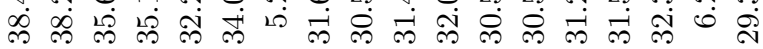

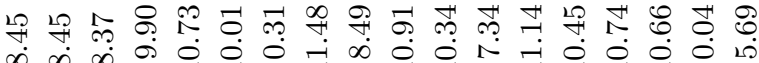

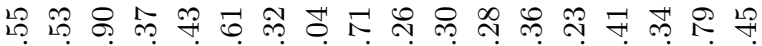

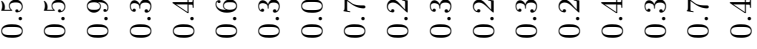

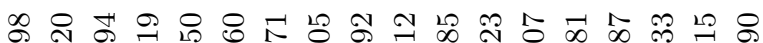
ণิ่

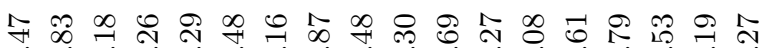

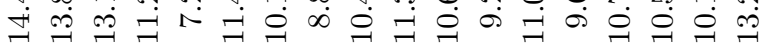

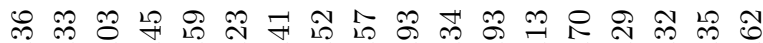

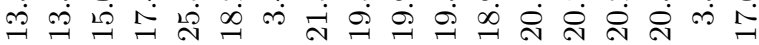

๘艹

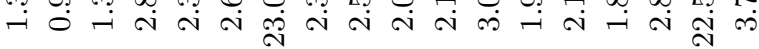

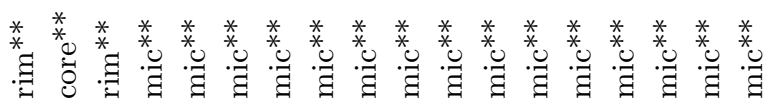

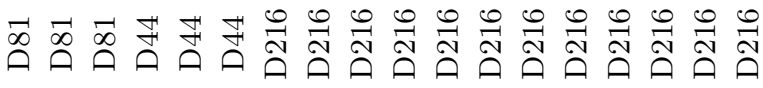

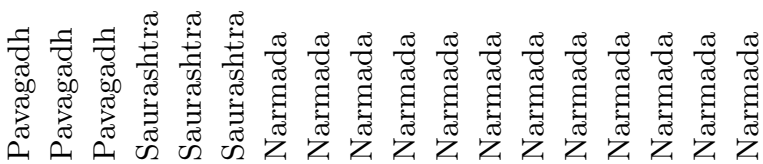

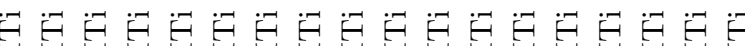

管

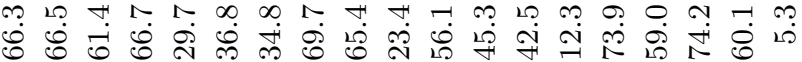

○. L

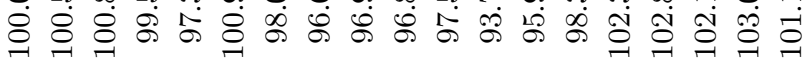

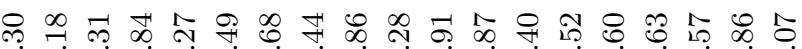
ฝิ ลิ่ ล่

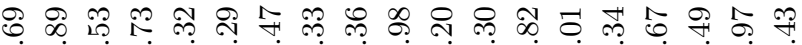

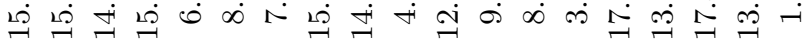

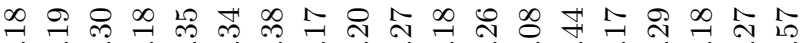

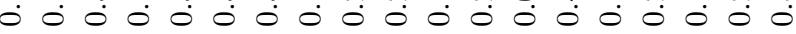

ఇ స

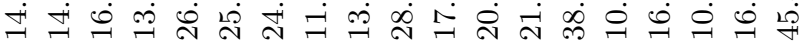

숭 人

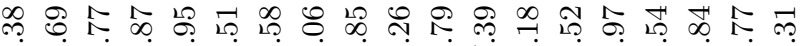

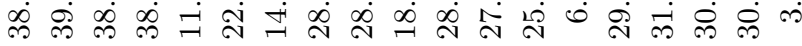

뉴 유 $\infty$ \% $0000+$ 开

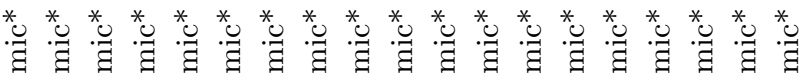

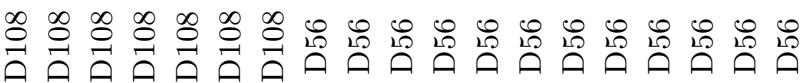

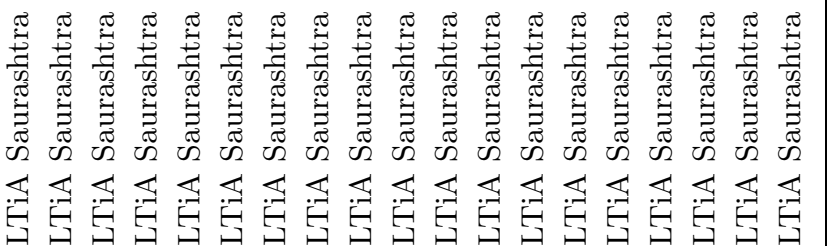




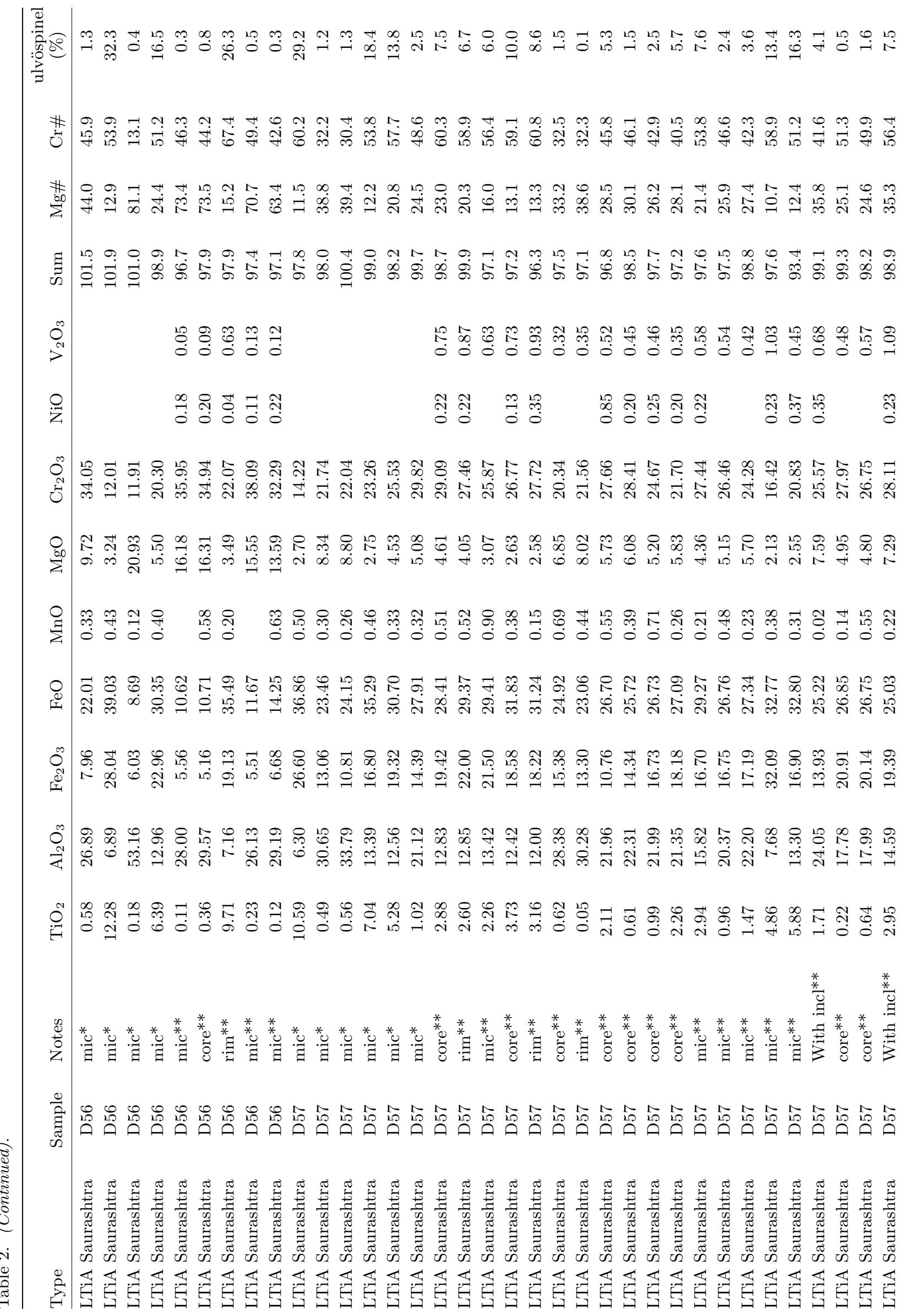




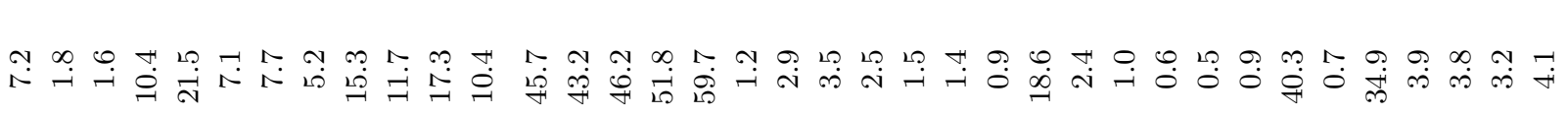

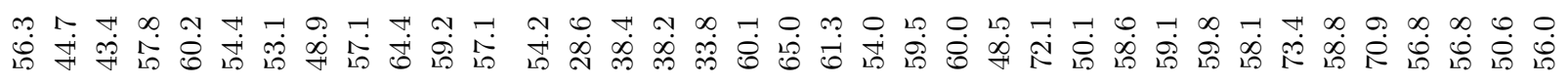

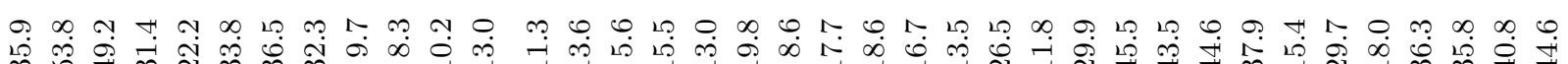

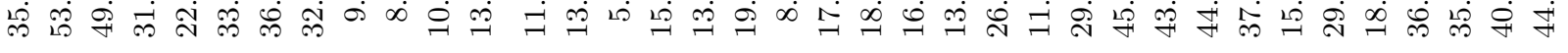
$\infty$ ㄴ. \& \&

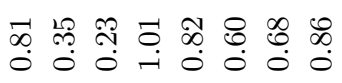

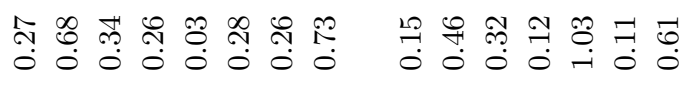

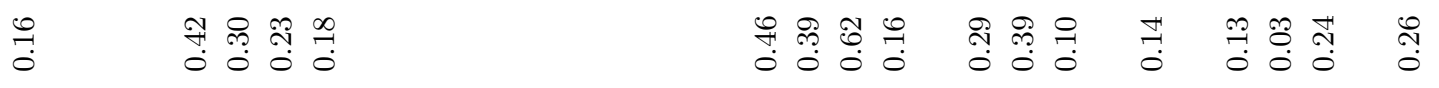

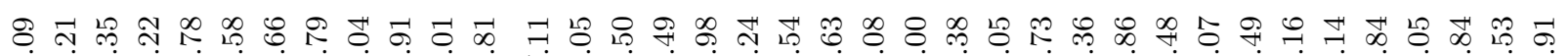
正

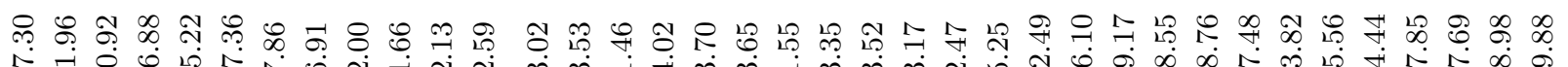

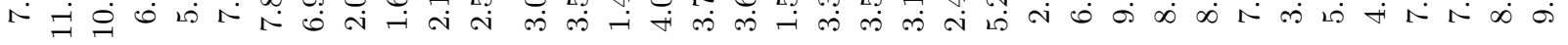

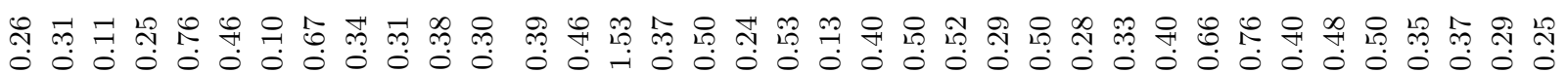
車 \่

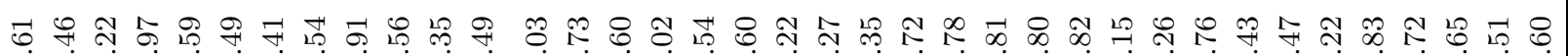

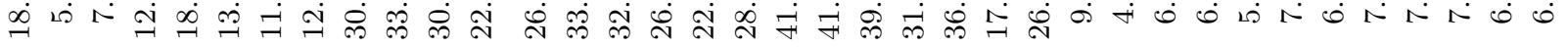

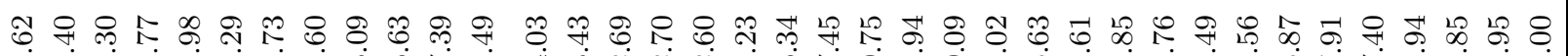

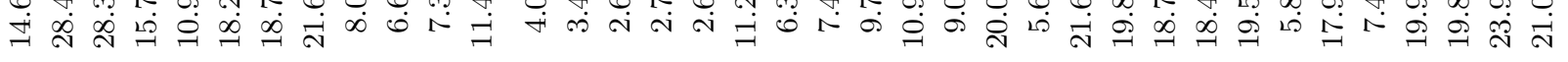

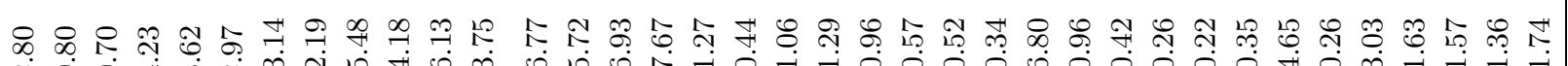
i $\begin{aligned} & \infty \\ & 0\end{aligned}$

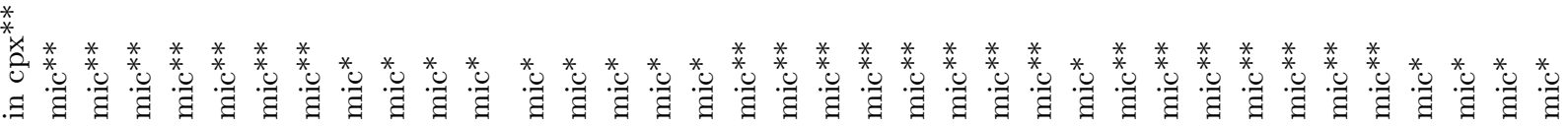

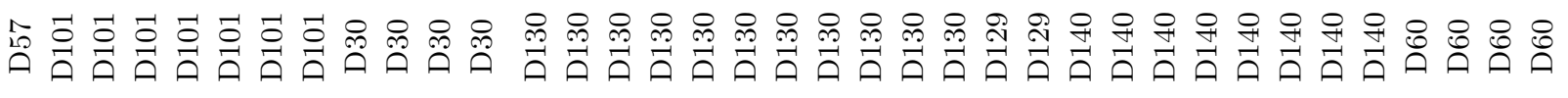

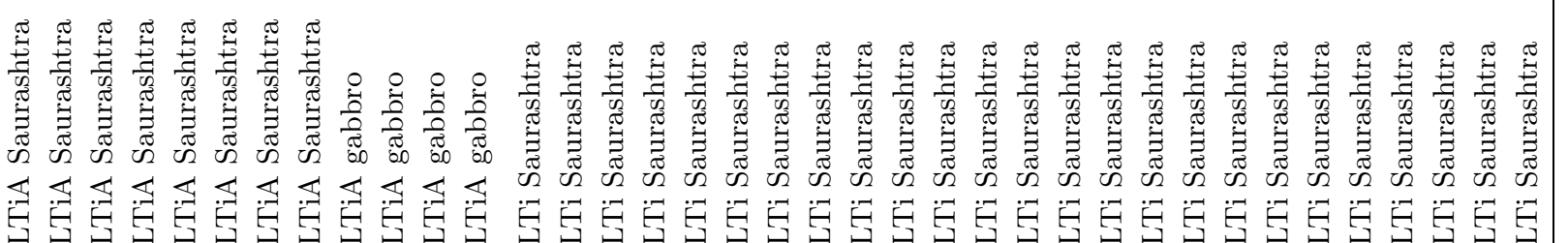




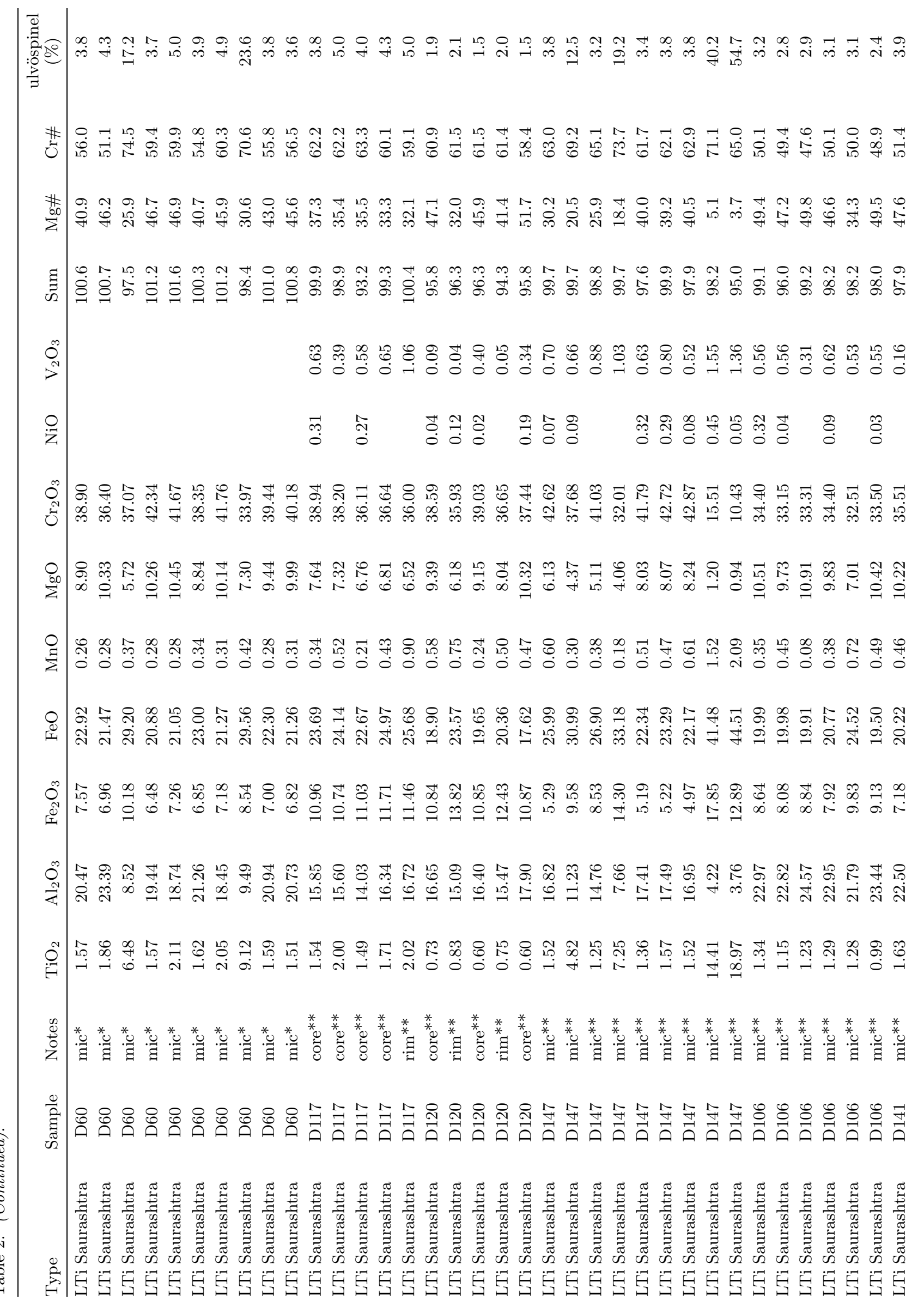




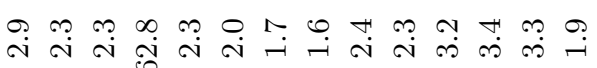

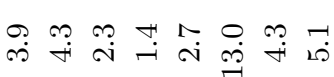

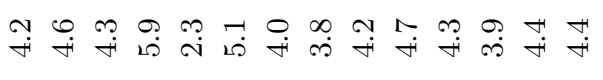

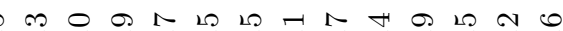

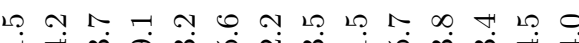
0. 

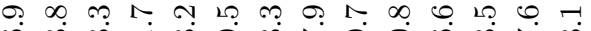
भ

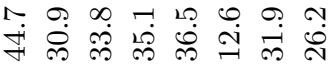

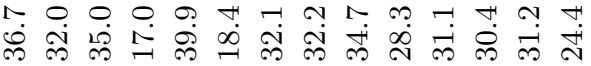

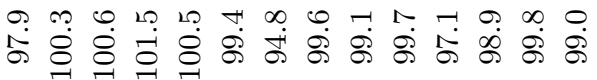
L L \&

○ ᄀ \& \& 뉴 东 ㅅำ

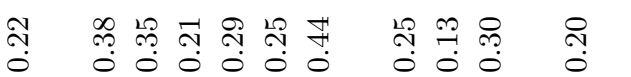

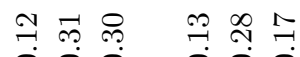

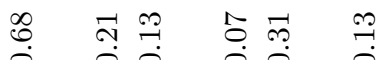

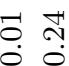
ใน 10 ก

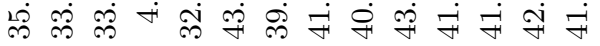
œ

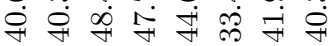

ผ

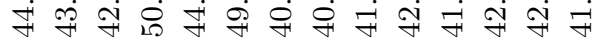

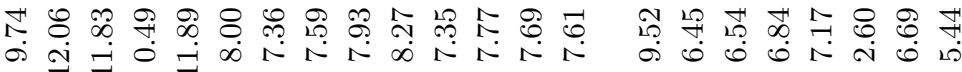

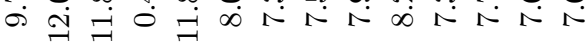

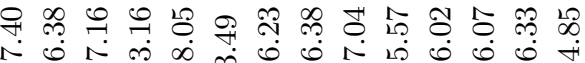

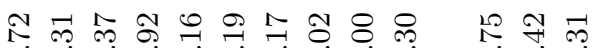

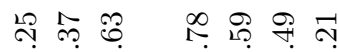

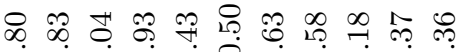

○े $\dot{0} \dot{0} \dot{0} \dot{0} \dot{0} \dot{0} \dot{0}$

8 为

ヘิ

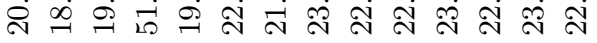

ลี

里 ค่

ஜ ஜ

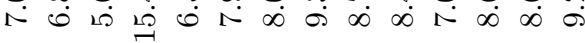

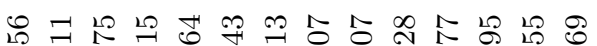

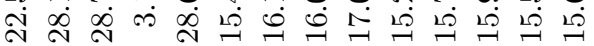

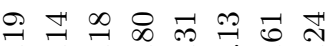

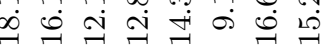

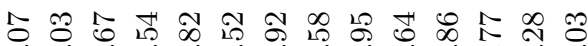

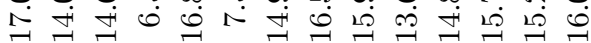

సิ 8 ○

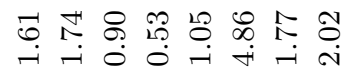

Гా

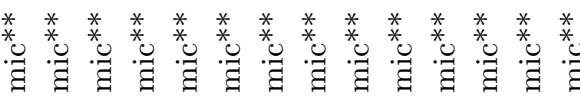
*.巳

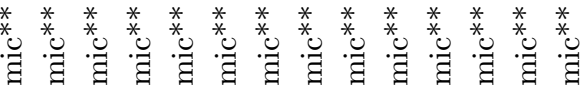

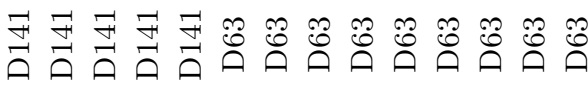

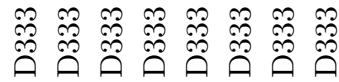

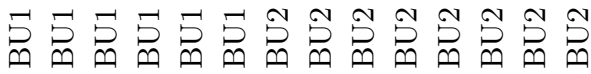

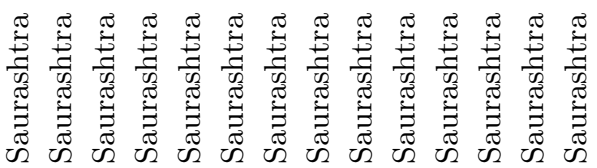

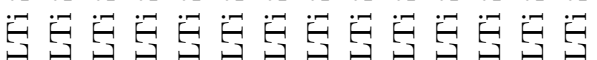

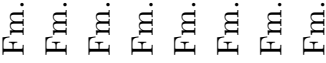

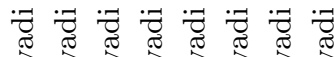

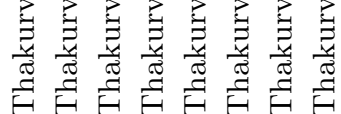

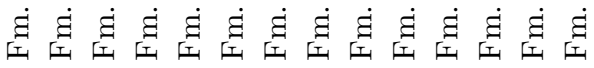

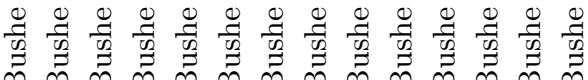




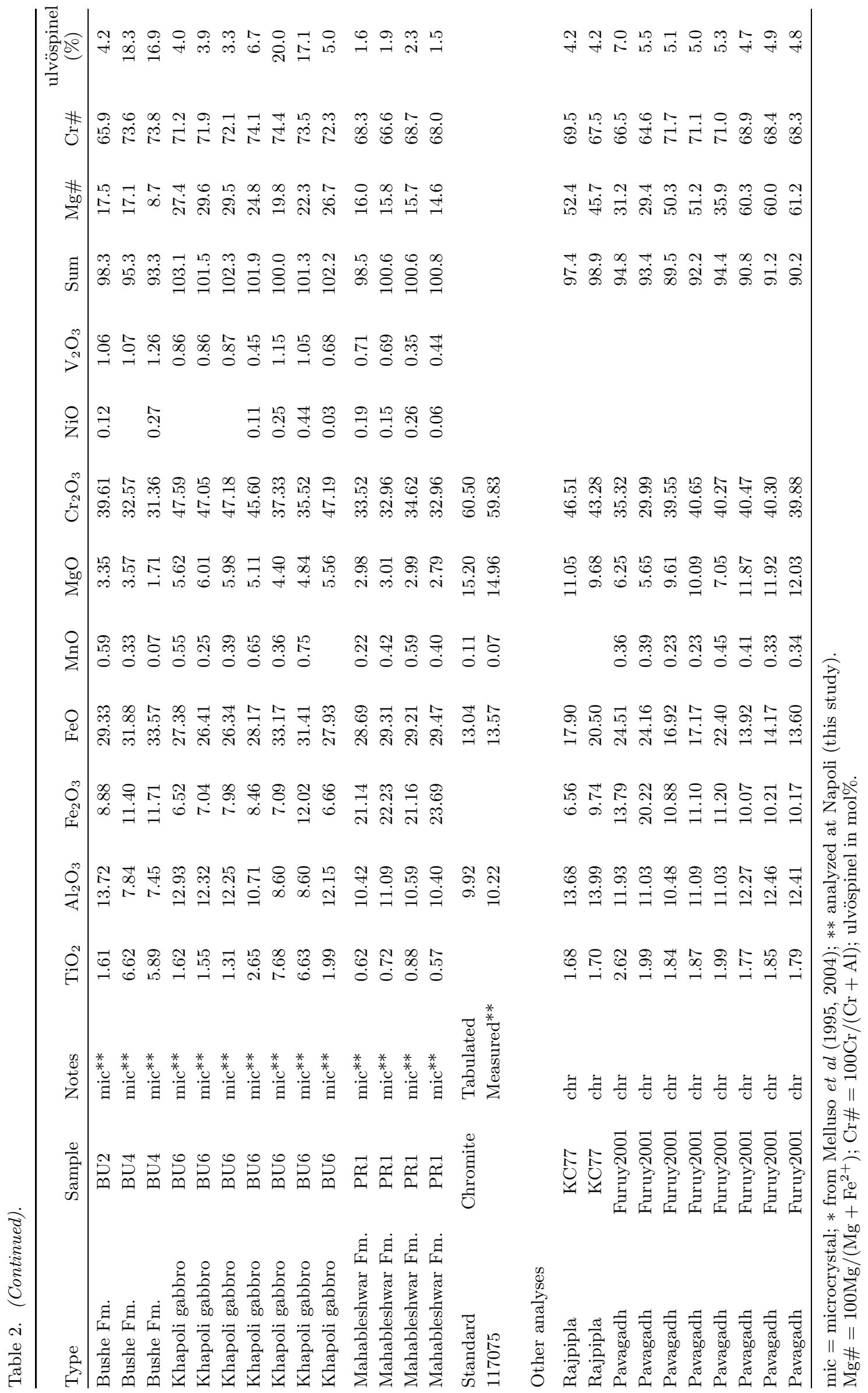


fifteen samples have been specifically analyzed for this study, whereas new data for the other samples have been integrated with previous work (Melluso 1992; Melluso et al 1995, 2004; Sheth and Melluso 2008). Additional spinel analyses of Deccan Trap rocks are taken from the literature (Krishnamurthy and Cox 1977; Furuyama et al 2001; table 2).

The spinel crystals, ranging in size from a few tens of microns to a few hundreds of microns, have been analyzed on polished thin sections. The energy dispersive system (EDS) analyses and backscattered electron images have been obtained utilizing an Oxford instruments Microanalysis equipped with a detector INCA X-act and a JEOL JSM-5310 microscope operating at $15 \mathrm{kV}$ and 50-100 mA, with a spot size of 15-17 microns and a net acquisition time of $50 \mathrm{~s}$. Measurements were elaborated with an INCA X-stream pulse processor. The following standards were used for calibration: diopside $(\mathrm{Mg}$ and $\mathrm{Fe})$, albite $(\mathrm{Al})$, rutile (Ti), vanadium (V), $\mathrm{Cr}_{2} \mathrm{O}_{3}(\mathrm{Cr})$, rhodonite $(\mathrm{Mn})$, pure nickel $(\mathrm{Ni})$. Spectral interferences were corrected in obtaining net peak intensities. Vanadium is reported as $\mathrm{V}_{2} \mathrm{O}_{3}$. The composition of standards measured for accuracy purposes (chromite 117075 of the Smithsonian Institution) is reported in table 2. Already published analyses of table 2 were obtained with ARL SEMQ at CNR, Cagliari, a Cameca SX50 at CNR, IGAG, Rome (analytical details in Melluso et al 1995, 2005).

\section{Results}

The full dataset is reported in table 2 .

The Cr-spinel of high-Ti picritic basalts cropping out in the sequences of Pavagadh (D81, D82, D97), central Saurashtra (D44) and Narmada river (D216) (Krishnamurthy and Cox 1977; Melluso et al 1995; Sheth and Melluso 2008) has a range in composition $\mathrm{Cr}_{2} \mathrm{O}_{3}=7-47.6 \mathrm{wt} . \%$ and $\mathrm{TiO}_{2}=0.99-23$ wt. $\%$, with ulvöspinel content ranging from 2.6 to $67.1 \mathrm{~mol} \%$. The $\mathrm{Cr} \#$ [molar $\mathrm{Cr} * 100 /(\mathrm{Cr}+\mathrm{Al})]$ and $\mathrm{Mg} \#$ [molar $\left.\mathrm{Mg} * 100 /\left(\mathrm{Mg}+\mathrm{Fe}^{2+}\right)\right]$ range from 50 to 75 and from 6 to 54, respectively. The highest $\mathrm{Cr} \#$ has been found in sample D97.

The Cr-spinel in the low-Ti picritic basalts of Saurashtra (D130, D129, D140, D141, D60, D147, D106, D63, D117, D120), which are the most primitive rocks of the most widespread magma type of the northwestern Deccan, have $\mathrm{Cr}_{2} \mathrm{O}_{3}$ content ranging from 5.1 to $38.9 \mathrm{wt} . \%$. The $\mathrm{TiO}_{2}$ contents range from 0.05 to $17.4 \mathrm{wt} . \%$, with ulvöspinel content ranging from 0.5 to $62.8 \mathrm{~mol} . \%$. The $\mathrm{Cr} \#$ and $\mathrm{Mg} \#$ range from 13 to 67 and from 5 to 81 , respectively.
The Cr-spinel in the low-TiA picritic basalts (D57, D56, D101, D108, and the gabbro D30) has by far the broadest compositional range. Most of this range is found in the spinel compositions of sample D56, which range in composition from one analysis with $\mathrm{Al}_{2} \mathrm{O}_{3}=53.2$ wt. $\%$ and $\mathrm{Cr}_{2} \mathrm{O}_{3}=$ 11.9 wt. $\%$, to $\mathrm{Al}_{2} \mathrm{O}_{3}=3.3$ wt. $\%, \mathrm{FeO}_{t}=70.5$ wt. $\%$ and $\mathrm{TiO}_{2}=17.4$ wt.\%, with ulvöspinel ranging from 0.1 to $47.6 \mathrm{~mol} . \%$. The sample D56 has also a very large range of olivine compositions (from $\mathrm{Fo}_{91}$ to $\mathrm{Fo}_{61}$ ); this feature certainly has relationships with the large range of chemical compositions in the enclosed spinels.

The Cr-spinel in the Bushe Fm. picritic basalts (BU1, BU2, BU4) reach some of the most $\mathrm{Cr}-$ rich compositions $\left(\mathrm{Cr}_{2} \mathrm{O}_{3}=31.4-50.7 \mathrm{wt} . \%\right)$. The $\mathrm{TiO}_{2}$ contents range from 0.9 to $7.86 \mathrm{wt} . \%$, with ulvöspinel content ranging from 2.3 to $20 \mathrm{~mol} . \%$. The Cr\# and Mg\# range from 62 to 82 and from 18 to 40, respectively. The Khapoli picritic gabbro BU6 has spinel with $\mathrm{Cr}_{2} \mathrm{O}_{3}$ content variable from 35 to $47 \mathrm{wt} . \%$ and ulvöspinel content from 3.3 to $20 \mathrm{~mol} . \%$.

The Cr-spinel in the Thakurvadi picritic basalt D333 has $\mathrm{TiO}_{2}$ contents in the range 0.5-4.86 wt.\%, with ulvöspinel content ranging from 1.4 to $13 \mathrm{~mol} . \%$, and $\mathrm{Cr}_{2} \mathrm{O}_{3}$ from 33.4 to $48.4 \mathrm{wt} . \%$. The $\mathrm{Cr} \#$ and $\mathrm{Mg} \#$ are in the range $60-73$ and $13-45$, respectively. The spinel analyses of the Mahabaleshwar Fm. picritic basalt PR-1, have Cr\# and $\mathrm{Mg} \#$ range from 67 to 69 , and from 15 to 16 , respectively.

The average $\mathrm{Cr} \#$ and $\mathrm{Mg} \#$ over 240 analyses are $57 \pm 11$ and $34 \pm 16$, respectively, with a marked cluster of compositions in the interval of $\mathrm{Cr} \#$ between 40 and 70 . The general core-to-rim variations (when crystals are chemically zoned) invariably indicate decrease of $\mathrm{Al}$ and $\mathrm{Mg}$ and increase of Fe and Ti components, whereas Cr may be roughly constant or decreases. Ti shows a positive correlation with $\mathrm{Fe}^{2+}$, and to a lower extent, with $\mathrm{Fe}^{3+}$. Vanadium and manganese contents also increase with $\mathrm{Fe}^{2+}$ and $\mathrm{Ti}$, as expected.

\subsection{Inclusions in spinel grains of low-TiA picritic basalts}

Mineral inclusions in some spinels of samples D56 and D57 offer another useful perspective. We observed a suite of subcalcic diopsides in a spinel of D56, already noted in Melluso et al (1995) (table 3; figures 4 and 5), with Mg\# tightly clustering between 86 and 88 (table 3 ). In addition, we have found an even more unusual range of compositions, ranging almost continuously from Al-poor orthopyroxene to aluminous diopside $(\mathrm{CaO}$ from 2.1 to 23.1 wt. $\% ; \mathrm{Al}_{2} \mathrm{O}_{3}$ from 0.8 to 11.7 wt.\%), with $\mathrm{Mg} \#$ ranging from 55 to 80 (table 3; figure 5) 


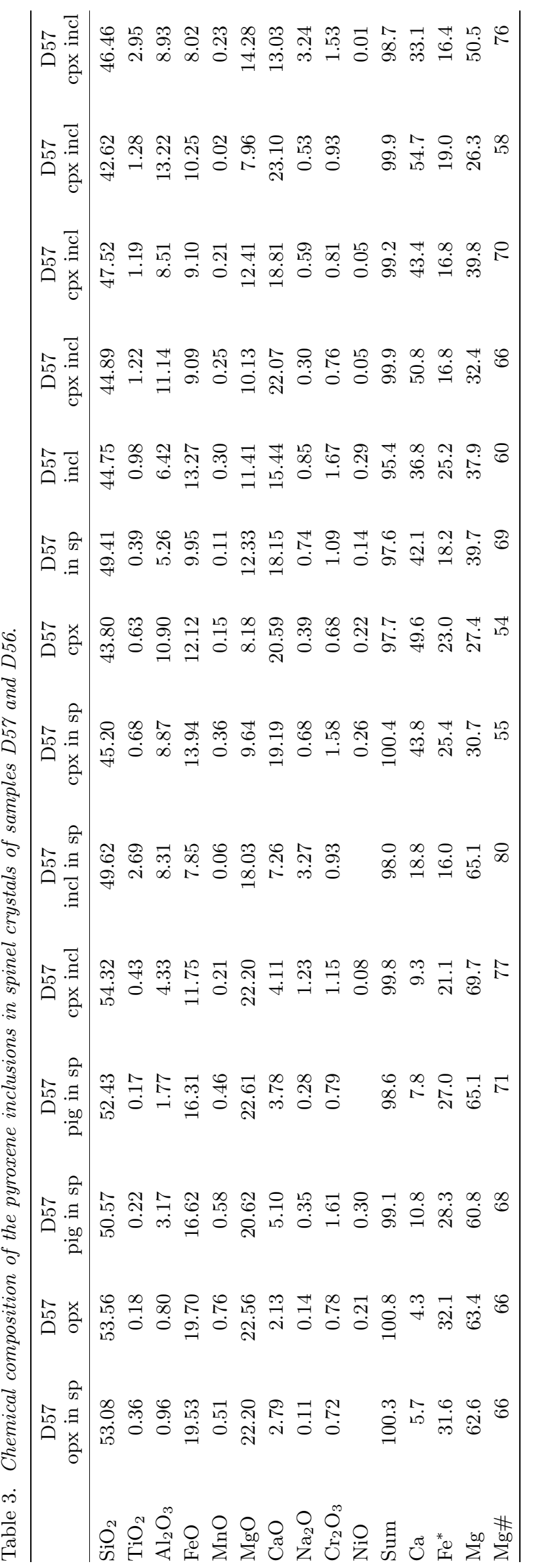

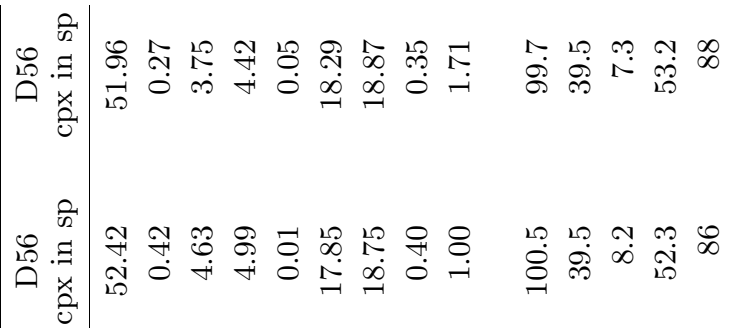

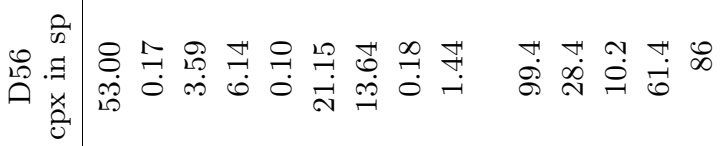

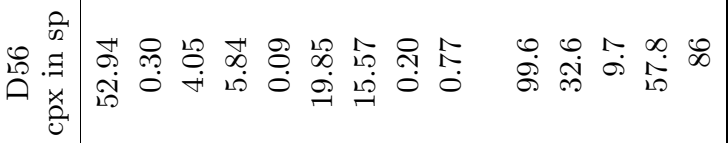

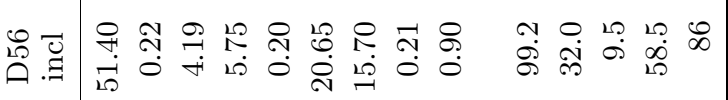

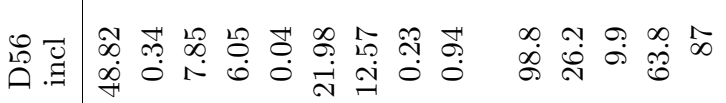

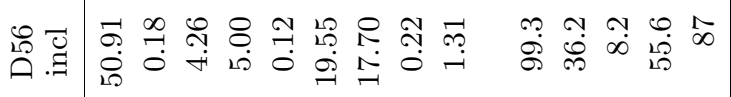

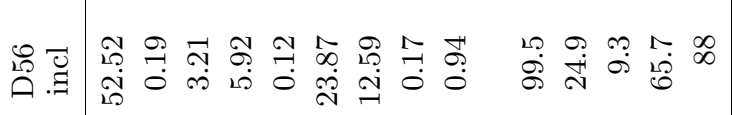

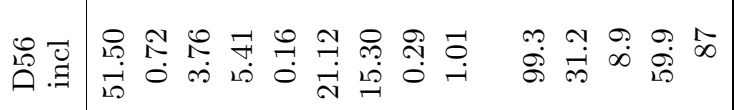

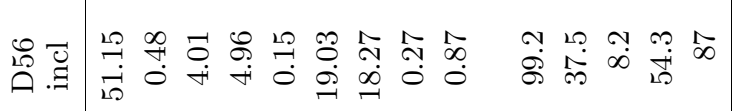

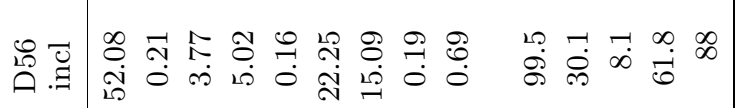

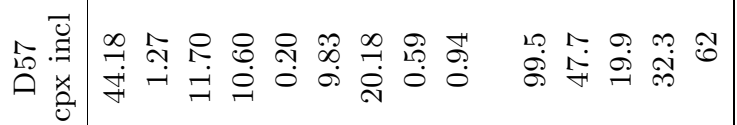

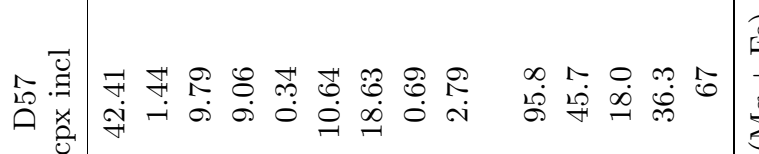
ㄴ.

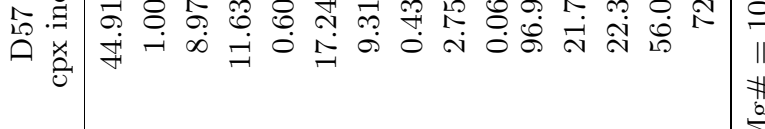

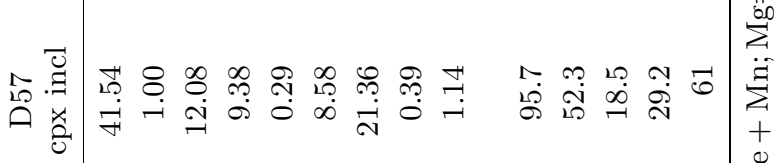

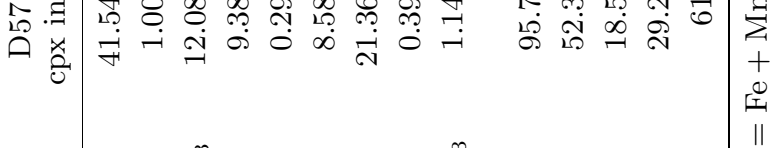

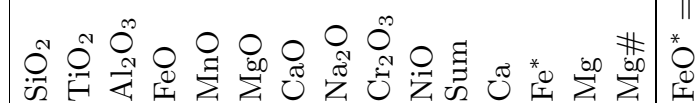



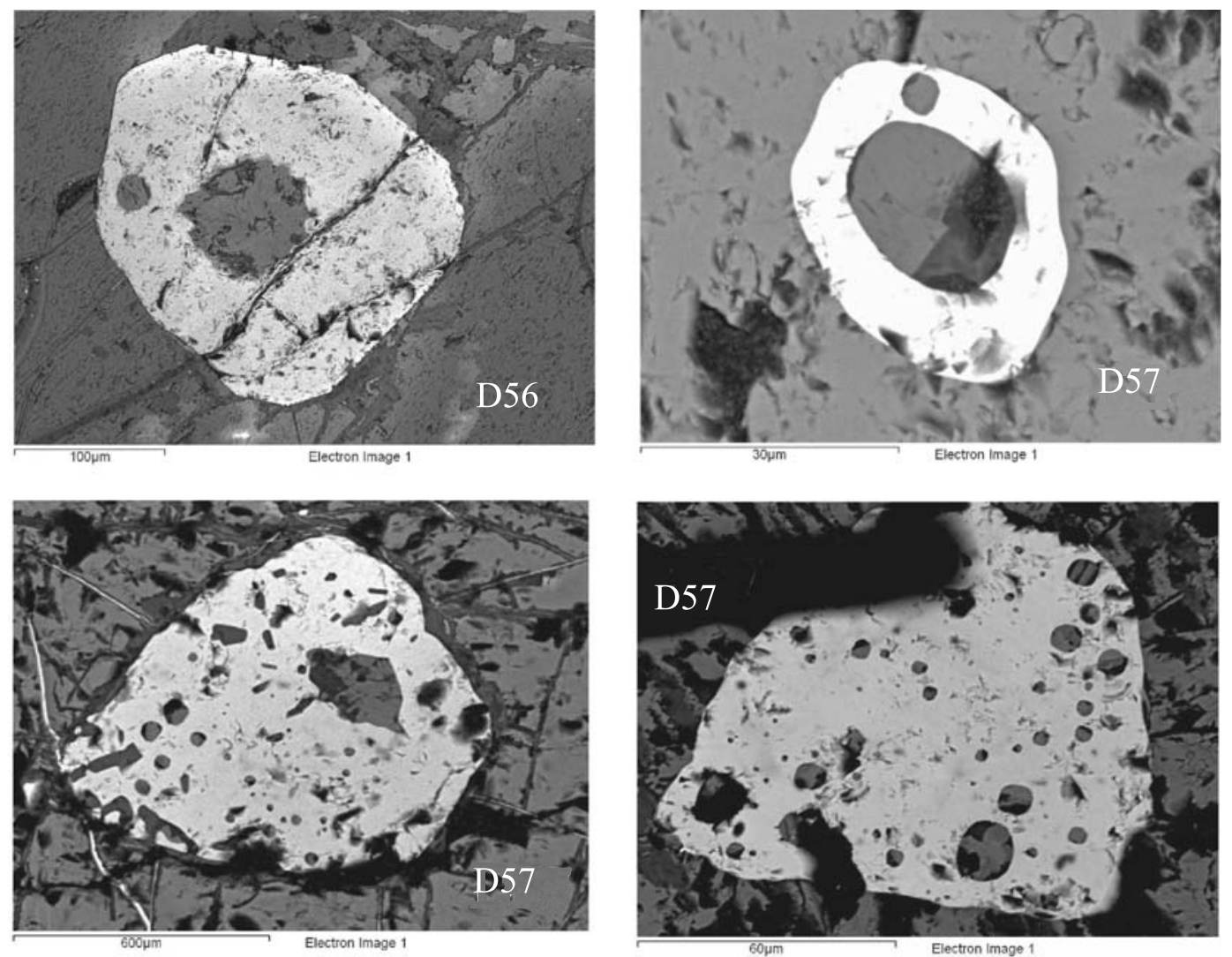

Figure 4. Backscattered electron images of pyroxene inclusions in spinels of the samples D56 and D57. Light minerals are almost completely unzoned chromites, darker inclusions are mainly pyroxene. The olivine phenocryst just around the spinel grain of D56 has composition Fo88.

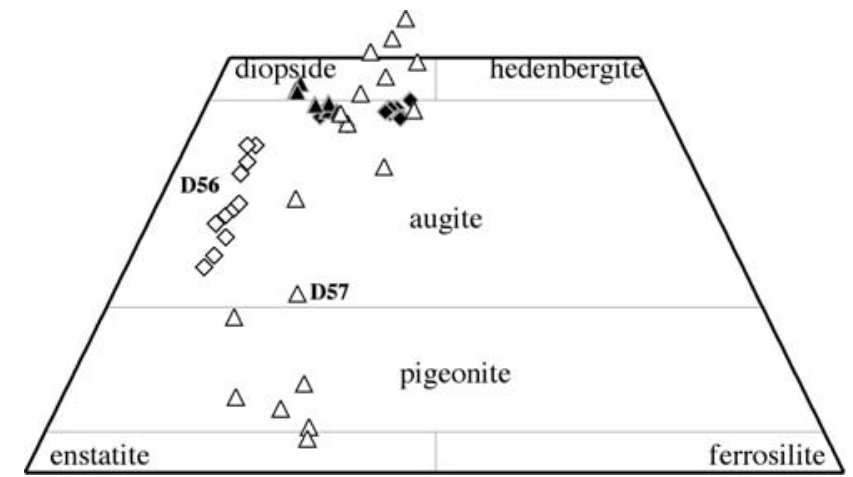

Figure 5. Pyroxene compositions of inclusions in spinel of samples D56 (rhombs) and D57 (triangles) as plotted in the $\mathrm{Ca}-\mathrm{Mg}-\mathrm{Fe}$ diagram (mol.\%). Some compositions plot above the $\mathrm{Ca}_{50}$ line due to the high content of non-quadrilateral components (high Al). The composition of the groundmass clinopyroxene of samples D56 and D57 is also plotted (same symbols in black).

in spinels of sample D57, along with calcic plagioclase and alteration minerals (zeolites and perhaps grossular-hydrogrossular), may be formed after glass. The clinopyroxene compositions reach $\mathrm{Al}_{2} \mathrm{O}_{3}=7.85 \mathrm{wt} . \%$ in the inclusions of D56 (table 3). These high $\mathrm{Al}_{2} \mathrm{O}_{3}$ contents are not linked to high $\mathrm{Fe}^{3+}$ or $\mathrm{Ti}$ contents, thus excluding the presence of molecules such as esseneite and $\mathrm{Ca}$-Ti-Tschermak. The $\mathrm{Al}^{\mathrm{VI}} / \mathrm{Al}^{\mathrm{IV}}$ ratios of clinopyroxene are high (from 0.28 to 0.99 , with similar ranges in the inclusions of both samples $\mathrm{D} 56$ and $\mathrm{D} 57$, average $\mathrm{Al}^{\mathrm{VI}} / \mathrm{Al}^{\mathrm{IV}}=0.55 \pm 0.21$ ). This indicates the presence of the Tschermak molecule $\mathrm{CaAl}_{2} \mathrm{SiO}_{6}$ [together with variable, but generally low, calculated amounts of jadeite, $\mathrm{Ca}-\mathrm{Cr}-\mathrm{Tschermak}\left(\mathrm{CaCrAlSiO}{ }_{6}\right)$, and other nonquadrilateral molecules].

\section{Discussion}

The data provided in this work allow a better overview of the composition of Deccan Trap spinels than previously available (Melluso et al 1995) and make this province at the same level of other major flood basalt provinces (Emeishan, Siberian Traps, Karoo; see figures 2 and 3 ) in terms of variation in chemistry of chromiferous spinel. The compositional range observed is more similar to that observed in tholeiitic intrusions rather than flood basalt provinces, but there is no evidence that the $\mathrm{Fe}-\mathrm{Ti}$ enrichment trend is subsolidus, given the 

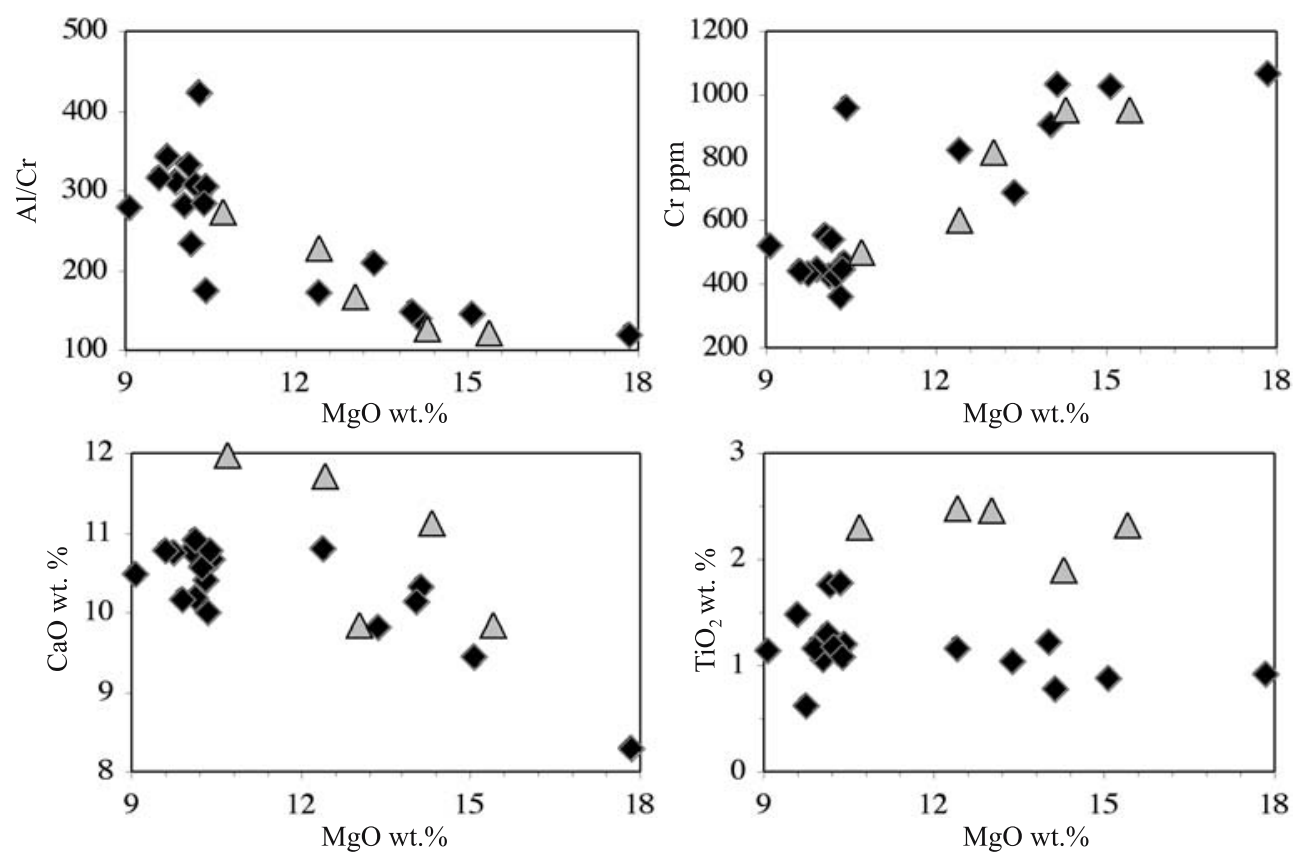

Figure 6. Chemical variations of the buk-rock compositions of this study vs. MgO wt.\% as variation index. The high-Ti samples are plotted as triangles, and the other samples as black rhombs. The marked increase of $\mathrm{Al} / \mathrm{Cr}$ and $\mathrm{CaO}$ indicates that these rocks suffered fractional crystallization of only olivine and chromiferous spinel in this compositional range.

structural position and the substantially unzoned spinel crystals studied here. The study of spinel inclusions in olivine phenocrysts apparently froze the actual composition of the mineral crystallizing from an evolving interstitial magma without the subsolidus re-equilibration found in igneous intrusions.

\subsection{Petrogenetic inferences}

The host Deccan picritic basalts and basalts (table 1) increase in $\mathrm{Al} / \mathrm{Cr}$ ratio with decreasing $\mathrm{MgO}$ ( $\mathrm{Al} / \mathrm{Cr}$ from 117 to 423), and have a marked $\mathrm{Cr}$ decrease with $\mathrm{MgO}$, coupled with a slight $\mathrm{Al}_{2} \mathrm{O}_{3}$ increase with decreasing $\mathrm{MgO}$. Therefore, if spinels are subject to normal partitioning mechanisms between $\mathrm{Cr}$ and $\mathrm{Al}$, they should become more $\mathrm{Al}-$ rich with the evolution, in the same way as the coexisting olivine increases in iron. Furthermore, the increase of $\mathrm{CaO}$ with decreasing $\mathrm{MgO}$ of the bulk rocks (the rocks plot along an olivine control line) is clear evidence that plagioclase and clinopyroxene were not strongly involved in the fractional crystallization sequence, at least in this crystallization interval, though they undoubtedly crystallized during intrasample cooling. Therefore, we can exclude that the decrease in $\mathrm{Al}$ of chromiferous spinel is caused by a concomitant decrease of $\mathrm{Al}_{2} \mathrm{O}_{3}$ in the melts, as is instead actually observed for the minor element $\mathrm{Cr}$ (figure 6). The compositional range of spinel (and coexisting olivine) warrants that, at some stage during magma crystallization,
Cr-bearing spinel may have co-crystallized with plagioclase and clinopyroxene.

The main substitutional mechanisms in the Deccan Trap spinels are related to the following cation exchanges: $\mathrm{Al}+\mathrm{Cr}=>\mathrm{Ti}+\mathrm{Fe}^{2+}$, $\mathrm{Mg}=>\mathrm{Fe}^{2+}$, and $\mathrm{Al}+\mathrm{Cr}=>\mathrm{Fe}^{3+}$. In the $\mathrm{Cr}-$ $\mathrm{Al}-\left(\mathrm{Fe}^{3+}+2 \mathrm{Ti}\right)$ diagram (figure $\left.2 \mathrm{a}\right)$, the Deccan chromiferous spinels show an overall curved trend, and this trend invariably points to the (magnetite-) ulvöspinel apex, as a consequence of decrease of $\mathrm{Al}$ - and Cr-spinel components (the $\mathrm{Fe}-\mathrm{Ti}$ trend of Barnes and Roeder 2001) (figures 2a and 7). It is worth noting that the most $\mathrm{Cr}$ - and $\mathrm{Al}$ poor spinels occur in the most Fe-rich olivines (down to $\mathrm{Fo}_{58-51}$ in gabbro D30), strongly suggesting that olivine and spinel co-crystallization had a severe effect on this latter. The spinels belonging to the different magma groups have distinct chemical trends, but always pointing to the magnetite+ulvöspinel end-members, particularly in high-Ti, low-Ti and low-TiA picritic basalts. The low-Ti, low-TiA and Bushe cover the complete compositional range from Al-rich to $\mathrm{Cr}$-rich and to Fe-Ti-rich varieties, whereas other types, such as the high-Ti basalts, have $\mathrm{Cr} \# \geq 40$ (figures 2 and 3$)$.

The trend towards magnetite and ulvöspinel with decreasing forsterite content of the host olivine, observed in the Deccan Trap spinels and more usual in spinel suites found in intrusive complexes (Eales and Snowden 1979; Wang et al 2005, 2008). We suggest the following sequence of events 

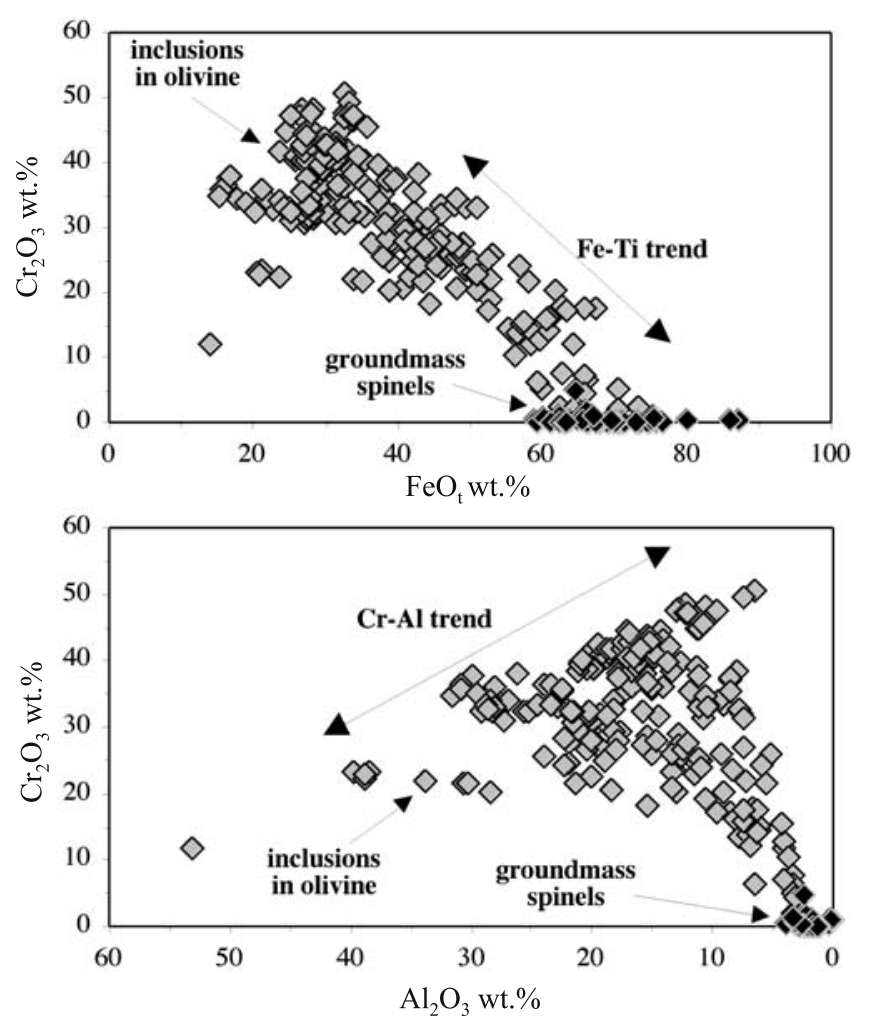

Figure 7. $\mathrm{FeO}_{t}$ vs. $\mathrm{Cr}_{2} \mathrm{O}_{3}$ and $\mathrm{Al}_{2} \mathrm{O}_{3}$ vs. $\mathrm{Cr}_{2} \mathrm{O}_{3}$ diagrams (oxides in wt.\%) for all the Deccan chromiferous spinels of this study (grey diamonds). The compositions of about 130 Deccan groundmass spinels (black diamonds) are also plotted (data from Melluso et al 1995; Melluso and Sethna 2010 and references therein).

involved in the chemical compositional trends of the Deccan spinels:

- depletion of $\mathrm{Mg}$ in the coexisting liquids due to olivine co-precipitation. The depletion of $\mathrm{Mg}$ close to the spinel crystals caused consequent poor availability of the $\mathrm{MgAl}_{2} \mathrm{O}_{4}$ component, due to the stronger affinity of $\mathrm{Al}$ for $\mathrm{Mg}$;

- contemporaneous decrease of $\mathrm{Cr}$ in spinel due to the drop in concentration of this element from the liquids close to the growing crystals;

- enrichment of $\mathrm{FeFe}_{2}^{3+} \mathrm{O}_{4}$ and $\mathrm{Fe}_{2} \mathrm{TiO}_{4}$, two endmembers more likely to crystallize from evolved tholeiitic liquids (being $\mathrm{Fe}^{3+}$ and $\mathrm{Ti}$ totally or strongly incompatible in olivine, plagioclase and clinopyroxene) and contemporaneously more prone to solid solution with $\mathrm{FeCr}_{2} \mathrm{O}_{4}$ than $\mathrm{MgAl}_{2} \mathrm{O}_{4}$.

We deduce that the trend towards Ti-rich compositions is likely a matter of favourable cationic substitutions in the structure of spinel (see also figure 17 of Roeder and Schulze 2008), where the relative substitutions of bivalent, trivalent and tetravalent cations are strictly interdependent. The trend has very poor correlation with the host magma chemistry, this latter being high or low in $\mathrm{TiO}_{2}$ (see also figure 6). This trend ultimately leads to the crystallization of Al-poor and Cr-free titanomagnetite of the groundmass (figure 7) without a clear compositional distinction of the least Cr-rich olivine inclusions.

Another possibility is that the large range of $\mathrm{Cr} \#$ of the Deccan chromiferous spinel, particularly those with the lowest $\mathrm{Ti}$ contents (figure 3), could be the result of crystallization from melts having variable degrees of polymerization. Increasing degree of melt polymerization can cause lower solubility of $\mathrm{Cr}$ in the melts, due to the well known preference of $\mathrm{Cr}^{3+}$ ion for six-fold coordination with oxygen, and therefore the first crystallized spinels could have relatively higher $\mathrm{Cr} \#$ than the coexisting melts. One evidence of this is given by the compositions of the low-TiA picritic basalts, which are very slightly alkaline (as testified by the presence of Ti-rich clinopyroxene), thus less polymerized than low-Ti, Bushe and Thakurvadi tholeiitic basalts. The relatively lower degree of polymerization in low-TiA picritic basalts, with respect to the low-Ti picritic basalts, could have caused the crystallization of a relatively Cr-poor spinel. The increasing magma polymerization after olivine crystallization should have favoured the stability of spinels with even higher $\mathrm{Cr} \#$ than those with higher $\mathrm{Mg}$ and $\mathrm{Al}$ contents, but with lower $\mathrm{Cr}$ contents, due to the depletion of this element in the residual liquids.

\subsection{Significance of the pyroxene inclusions}

Qualitative estimates of the equilibration pressures by using the clinopyroxene barometer of Nimis (1999) range from 5 to $13 \mathrm{kbar}$ for the inclusions in D56 and from 4 to $17 \mathrm{kbar}$ for the clinopyroxene inclusions of D57. These compositions are not very different from those of other spinel inclusions reported by Della-Pasqua et al (1994). The pyroxenes of D57 could be disequilibrium compositions grown in melt inclusions (cf. figure 4), but the inclusions in D56 are strictly monophase (figure 4). Worth to remind, samples D56 and D57 have titaniferous augite-diopside as the only pyroxene outside spinel grains (and, of course, no trace of pigeonite or orthopyroxene), as typical of weakly alkaline rocks (figure 5). Therefore, we suggest that the inclusions of spinel in sample D56 suggest a higher pressure stage of crystallization, whereas the inclusions in D57 can be disequilibrium compositions nucleated in melt pockets around growing spinels. The possibility that these spinels formed in liquid compositions different from those the spinels were finally entrained can be also taken in consideration. Evidence of magma mixing or simply entrainment of xenocrysts in the Deccan is quite 


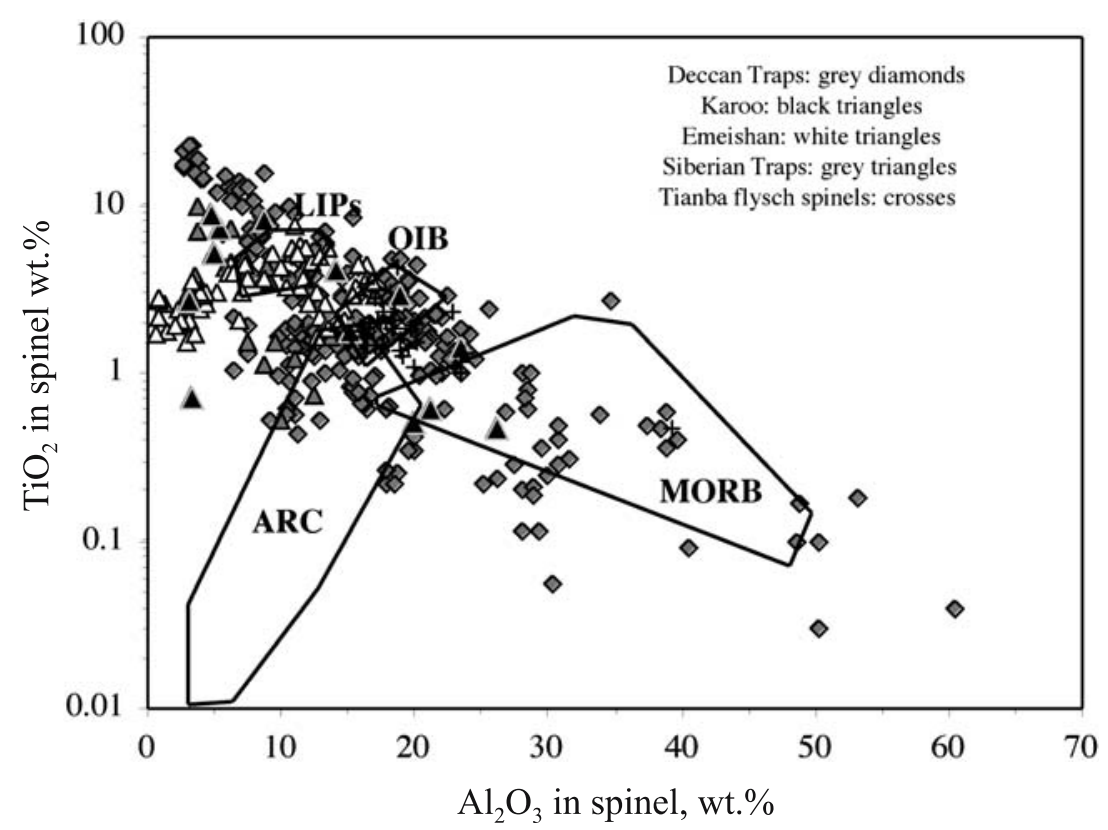

Figure 8. $\mathrm{TiO}_{2}-\mathrm{Al}_{2} \mathrm{O}_{3}$ diagram discriminant of spinels from various tectonic settings (after Kamenetsky et al 2001) with all the Deccan Trap chromiferous spinels of this study (grey diamonds). We plotted our complete dataset, but the situation changes little after plotting the compositions of chromites in olivines with Fo > 84 mol.\%, as suggested by Kamenetsky et al (2001). We plotted data on Siberian Traps, Emeishan and Karoo spinels (Eales and Snowden 1979; Barnes and Kunilov 2000; Wang et al 2005, 2008). Most data plot well outside the LIPs field. The spinels found in the Late Cretaceous Tianba flysch, southern Tibet, thought to derive from dismantled Rajmahal Traps volcanic rocks (Zhu et al 2004), are also plotted.

scarce, but it is also difficult to find traces of these processes, given the substantially uniform basaltic chemistry and mineral composition of the erupted products.

\subsection{Links with mantle composition}

When the data of the most $\mathrm{Cr}$ - and Al-rich and $\mathrm{Ti}-\mathrm{Fe}^{3+}$-poor Deccan spinels are considered together with mantle-derived spinel suites (figure 2a), we note that some of the Deccan spinels have a trend subparallel to that of mantle (the Al-Cr trend of Barnes and Roeder 2001), though mantle spinel suites are very distinct from the Deccan Trap spinels (and other spinel suites) at a given $\mathrm{Cr} \#$ (figure $2 \mathrm{~b}$ ). The cause of the differences in $\mathrm{Cr} \#, \mathrm{Mg} \#$ and $\mathrm{Ti}$ between mantle and magmatic spinels is the key transition to infer mantle characteristics in the latter. As shown in several papers, the chemical composition of mantle spinel itself (e.g., Dick and Bullen 1984), or coupled with the forsterite content of coexisting olivine (e.g., Arai 1994), are features widely used to infer relatively fertile or melt-depleted sources.

If we backtrack the variation in chemistry of Deccan spinels towards the spinel range in typical and variably melt-depleted mantle lithologies (lherzolite, wehrlite, harzburgite and dunite; figures $2 \mathrm{~b}$ and 3), the wide range of $\mathrm{Cr} \#$ of the Deccan spinels could be thought to be a result of partial melting of lherzolitic (rarely) to harzburgitic/dunitic mantle. Nonetheless, a 'residual' (dunitic or harzburgitic) mantle source must be considered as completely unrealistic and meaningless for the Deccan picritic basalts. Indeed, these basalts have relatively 'normal' $\mathrm{CaO}, \mathrm{Fe}_{2} \mathrm{O}_{3 t}, \mathrm{Na}_{2} \mathrm{O}$ and $\mathrm{Al}_{2} \mathrm{O}_{3}$ contents for them being tholeiitic or weakly alkaline in affinity (table 1), implying derivation from variable degrees of aggregated melting of broadly lherzolitic sources (Melluso et al 2006a). The $\mathrm{Cr} \#$ and $\mathrm{Mg} \#$ of magmatic spinels thus is far from being a simple function of the mantle source composition of the magma from which the spinel crystallized (even in association with the composition of coexisting olivine). If we also consider that melting could have taken place starting from the garnet stability field (see also Melluso et al 2006a), any link between $\mathrm{Cr} \#$ of magmatic spinel inclusions and the mantle sources is wholly conjectural.

\subsection{The tectonic setting of the Deccan Traps deduced from chemistry of chromiferous spinels}

When plotted in the $\left(\mathrm{TiO}_{2}-\mathrm{Al}_{2} \mathrm{O}_{3}\right)$ tectonic discrimination diagram of Kamenetsky et al (2001) (figure 8), the Deccan Trap chromiferous spinels of this study encompass a far broader field than that is expected to be typical of LIPs. The data actually cover all the fields from LIPs, through OIB 
(ocean island basalt), to MORB (mid-ocean ridge basalt) and, partially, even ARC-related spinels, extending also far beyond; the most $\mathrm{Cr}-$ and $\mathrm{Al}-$ rich spinels of Deccan plot far outside the LIPs field, even if we limit the dataset to spinels included in olivine with Fo $>84$ mol.\%. Actually, very few Deccan analyses plot within the field believed to be typical of LIPs. The composition of chrome spinels in the low-TiA basalts is that most similar to MORB spinels (cf. Dick and Bullen 1984; Allan et al 1988; Barnes and Roeder 2001; figure 8). Of course, this cannot be considered as evidence of a MORB-related genesis of these basalt types, but it is simply an evidence of similar petrogenetic processes leading to spinel crystallization, processes which are far from being fully understood (see also Barnes and Roeder 2001). Any inference deduced by $\mathrm{TiO}_{2}$ and $\mathrm{Al}_{2} \mathrm{O}_{3}$ content of spinels is therefore dubious when applied to the Deccan Traps case, given the undisputed tectonic setting of this LIP. The reverse application of this diagram to the identification of the tectonic setting just using a few spinel populations, randomly found in sedimentary sequences, could also lead to dubious deductions about the tectonic provenance.

\section{Conclusions and open problems}

The study of the chemical composition of chromiferous spinels in the Deccan Traps mafic volcanic rocks have brought to the following deductions and still open problems:

The Deccan Trap spinels have a very large range of $\mathrm{Al}$ and $\mathrm{Cr}$ and trend to $\mathrm{Fe}$ and Ti-rich compositions. This implies both crystallization from a range of parental magmas, a relatively prolonged cotectic crystallization with olivine, and, finally, crystallization from increasingly evolved local, interstitial, melts. All these features occurred at crustal pressure, causing enrichment in $\mathrm{Fe}$ and $\mathrm{Ti}$ and depletion in $\mathrm{Cr}$ and $\mathrm{Al}$ in the spinel. The large compositional range found (not too dissimilar from the large range of coexisting olivine compositions, see above and table 1) is an indication of a relatively slow cooling rate of the magmas, similar to that expected in shallow magma reservoirs.

The Bushe Fm., the Thakurvadi Fm. and some of the high-Ti basalts of the Pavagadh section have the most Cr-rich spinels, accompanied by low $\mathrm{Mg} \#$, completely unlike typical mantle spinel trends. On the other hand, the low-TiA basalts have the most Al-rich and Cr-poor spinels. This latter feature could be considered as evidence of a magma crystallization environment not too dissimilar to that which generated Al-rich spinels in MORB. Melt polymerization may also have had a role in the spinel crystallization. Links between magmatic spinel chemistry and mantle source processes, as proposed elsewhere, are only matter of conjecture, at least in the Deccan Traps case.

The dataset reported here documents the notable chemical variations of the oxides in the Deccan Traps, similarly to the other major LIPs featuring primitive magma compositions or olivinerich mafic tholeiitic intrusions. This paper also provides a basis for the search of Deccan-related chromiferous spinel compositions in the post-K/T detritic successions around India and elsewhere. The dispersion of mafic tephra layers related to the Deccan Traps throughout the earth, as opposed to non-terrestrial input to the sedimentary record due to the Chicxulub impact event (Keller et al 2003), or other origins (Grachev et al 2007) are certainly topics worthy of more detailed study.

\section{Acknowledgements}

We dedicate this paper to the memory of Giorgio Rivalenti, an invaluable guide in the study of maficultramafic igneous rocks and mantle processes. Thanks are due to Carlo Garbarino and Marcello Serracino for their precious assistance in the microprobe work over the years, first at Cagliari and then at Rome, Vincenza Guarino and Ciro Cucciniello for their help with laboratory work, and Piero Brotzu, Sam Sethna, Luigi Beccaluva, Lucio Morbidelli, Arrigo Gregnanin and Gianbosco Traversa for discussions and continuous support over the years. Peter Roeder is gratefully thanked for the discussions after reading an early draft of the manuscript. Reviews of Stephen Barnes on early versions were also appreciated. The thoughtful official reviews of Sisir Mondal and Surendra Verma were much appreciated. This project was granted by MURST-MIUR and Fondi Ricerca Dipartimentale 2008.

\section{References}

Ahmad M and Shrivastava J P 2004 Iron-titanium oxide geothermometry and petrogenesis of lava flows and dykes from Mandla lobe of the eastern Deccan volcanic province, India; Gondwana Res. 7 563-577.

Allan J F, Sack R O and Batiza R 1988 Cr-rich spinels as petrogenetic indicators: MORB-type lavas from the Lamont seamount chain, eastern Pacific; Am. Mineral. 73 741-753.

Arai S 1994 Characterization of spinel peridotites by olivinespinel compositional relationships: Review and interpretation; Chem. Geol. 113 191-204.

Barnes S J and Kunilov V Y 2000 Spinels and Mg-ilmenites from the Noril'sk 1 and Talnakh intrusions and other mafic rocks of the Siberian flood basalt province; Econ. Geol. 95 1701-1717. 
Barnes S J and Roeder P L 2001 The range of spinel compositions in terrestrial mafic and ultramafic rocks; J. Petrol. 42 2279-2302.

Beane J E and Hooper P R 1988 A note on the picrite basalts from the Western Ghats, Deccan Traps, India; Geol. Soc. India Memoir 10 117-133.

Beane J E, Turner C A, Hooper P R, Subbarao K V and Walsh J N 1986 Stratigraphy, composition and form of the Deccan basalts, Western Ghats, India; Bull. Volcanol. 48 61-83.

Bernstein S, Hanghøj K, Kelemen P B and Brooks C K 2006 Ultra-depleted, shallow cratonic mantle beneath West Greenland: Dunitic xenoliths from Ubekendt Ejland; Contrib. Mineral. Petrol. 152 335-347.

Cawthorn R G and Biggar G M 1993 Crystallization of titaniferous chromite, magnesian ilmenite and armalcolite in tholeiitic suites in the Karoo Igneous Province; Contrib. Mineral. Petrol. 114 221-235.

Chenet A-L, Quidelleur X, Fluteau F, Courtillot V and Bajpai S $2007{ }^{40} \mathrm{~K}-{ }^{40} \mathrm{Ar}$ dating of the main Deccan large igneous province: Further evidence of KTB age and short duration; Earth Planet. Sci. Lett. 263 1-15.

Cox K G and Hawkesworth C J 1985 Geochemical stratigraphy of the Deccan Traps at Mahabaleshwar, Western Ghats, India, with implication for open system processes; J. Petrol. 26 355-387.

Collier J S, Sansom V, Ishizuka O, Taylor R N, Minshull T A and Whitmarsh R B 2008 Ages of Seychelles-India breakup; Earth Planet. Sci. Lett. 272 264-277.

Della-Pasqua F N, Kamenetsky V S, Gasparon M, Crawford A J and Varne R 1994 Al-spinels in primitive arc volcanics; Mineral. Petrol. 53 1-26.

Devey C W and Stephens W E 1992 Deccan-related magmatism west of the Seychelles-India rift; In: Magmatism and the causes of continental break-up; Storey B C, Alabaster T and Pankhurst R J (eds); Geol. Soc. London, Spec. Publ. 68 271-291.

Dick H J B and Bullen T 1984 Chromian spinel as a petrogenetic indicator in abyssal and alpine-type peridotites and spatially associated lavas; Contrib. Mineral. Petrol. 86 54-76.

Eales H V and Snowden D V 1979 Chromiferous spinels of the Elephant's Head dike; Econ. Geol. 14 227-242.

Finnigan C G, Brenan J M, Mungall J E and McDonough W F 2008 Experiments and models bearing on the role of chromite as a collector of platinum group minerals by local reduction; J. Petrol. 49 1647-1665.

Furuyama K, Hari K R and Santosh M 2001 Crystallization history of primitive Deccan basalt from Pavagadh hill, western India; Gondwana Res. 4 427-436.

Garuti G, Pushkarev E V, Zaccarini F, Cabella R and Anikina E 2003 Chromite composition and platinumgroup mineral assemblage in the Uktus Uralian-Alaskantype complex (Central Urals, Russia); Mineralium Deposita 38 312-326.

Grachev A F, Tselmovich V A, Korchagin O A and Kollmann H A 2007 Two spinel populations from the Cretaceous-Paleogene $(\mathrm{K} / \mathrm{T})$ boundary clay layer in the Gams stratigraphic sequence, eastern Alps; Russian J. Earth Sci. 9 ES2002, doi: 10.2205/2007/ES000297.

Gradstein F M, Ogg J G, Smith A G, Bleeker W and Lourens L J 2004 A new geologic time scale with special reference to Precambrian and Neogene; Episodes 27 83-100.

Hellebrand E, Snow J E, Hoppe P and Hofmann A W 2002 Garnet-field melting and late-stage refertilization in residual abyssal peridotites from the Central Indian Ridge; J. Petrol. 43 2305-2338.
Kamenetsky V S, Crawford A J and Meffre S 2001 Factors controlling chemistry of magmatic spinel: An empirical study of associated olivine, Cr-spinel and melt inclusions from primitive rocks; J. Petrol. 42 655-671.

Keller G, Stinnesbeck W, Adatte T and Stüben D 2003 Multiple impacts across the Cretaceous-Tetriary boundary; Earth Sci. Rev. 62 327-363.

Khadri S F R, Subbarao K V and Walsh J N 1999 Stratigraphy, composition and form of the east Pune basalts, western Deccan basalt province, India; In: Deccan Volcanic province, Subbarao K V (ed.); Geol. Soc. India Memoir 43 179-202.

Krishnamurthy P and Cox K G 1977 Picrite basalts and related lavas from the Deccan Traps of Western India; Contrib. Mineral. Petrol. 62 53-75.

Krishnamurthy P, Pande K, Gopalan K and Macdougall J D 1988 Upper mantle xenoliths in alkali basalts related to Deccan Trap volcanism; In: Deccan Flood Basalts, Subbarao K V (ed.); Geol. Soc. India Memoir 10 53-67.

Krishnamurthy P, Pande K, Gopalan K and Macdougall J D 1999 Mineralogical and chemical studies on alkaline basaltic rocks of Kutch, Gujarat, India; In: Deccan Volcanic Province, Subbarao K V (ed.), Geol. Soc. India Memoir 43 757-783.

Lee Y I 1999 Geotectonic significance of detrital chromian spinel: A review; Geosci. J. 3 23-29.

Lightfoot P C, Hawkesworth C J, Devey C W, Rogers N W and Van Calsteren P W C 1990 Source and differentiation of Deccan Trap lavas: Implications of geochemical and mineral chemical variations; J. Petrol. 31 1165-1200.

Mahoney J J 1988 Deccan Traps; In: Flood Basalts, Macdougall J D (ed.), pp 151-194, Kluwer, Dordrecht.

Mahoney J J, Duncan R A, Khan W, Gnos E and McCormick G R 2002 Cretaceous volcanic rocks of the south Tethyan suture zone, Pakistan: Implications for the Reunion hotspot and Deccan Traps; Earth Planet. Sci. Lett. $203295-310$.

Mahoney J J, Sheth H C, Chandrasekharam D and Peng Z X 2000 Geochemistry of flood basalts of the Toranmal section, northern Deccan Traps, India: Implications for regional Deccan stratigraphy; J. Petrol. 41 1099-1120.

Melluso L 1992 Caratteristiche petrologiche e geochimiche di vulcaniti continentali del Deccan, India; PhD thesis, Ferrara University, 140p, unpublished.

Melluso L, Beccaluva L, Brotzu P, Gregnanin A, Gupta A K, Morbidelli L and Traversa G 1995 Constraints on the mantle sources of the Deccan Traps from the petrology and geochemistry of the basalts of Gujarat State (Western India); J. Petrol. 36 1393-1432.

Melluso L, Barbieri M and Beccaluva L 2004 Petrogenesis and regional chemical correlations of the flood basalt sequence in the Central Deccan Traps, India; J. Earth Syst. Sci. 114 587-603.

Melluso L, Morra V, Brotzu P, Tommasini S, Renna M R, Duncan R A, Franciosi L and d'Amelio F 2005 Geochronology and petrogenesis of the Cretaceous Antampombato-Ambatovy complex and associated dyke swarm, Madagascar; J. Petrol. 46 1963-1996.

Melluso L, Mahoney J J and Dallai L 2006a Mantle sources and crustal input as recorded in High-Mg Deccan Trap basalts of Gujarat (India); Lithos 89 259-274.

Melluso L, Morra V and Fedele L 2006b An overview of phase chemistry and magmatic evolution in the Cretaceous flood basalt province of northern Madagascar; Periodico di Mineralogia $\mathbf{7 5}$ 175-188.

Melluso L and Sethna S F 2010 Mineral composition of the Deccan Trap volcanic rocks, India: An overview; In: 
Topics in Igneous Petrology: A Tribute to Prof Mihir K Bose, Ray J, Sen G and Ghosh B (eds), Springer, in press.

Mukherjee A B and Biswas S 1988 Mantle derived spinel lherzolite xenoliths from Deccan Volcanic province, India: Implication for the thermal structure of the lithosphere underlying the Deccan Traps; J. Volcanol. Geoth. Res. 35 269-276.

Murari R, Krishnamurthy P, Tikhonenko P I and Gopalan K 1993 Magnesian ilmenites in picrite basalts from Siberian and Deccan Traps - additional mineralogical evidence for primary melt compositions (?); Min. Mag. $\mathbf{5 7}$ 733-735.

Najman Y, Bickle M J, Bou-Dagher-Fadel M, Carter A, Garzanti E, Paul M, Wijbrans J, Willett E, Oliver G, Parrish R, Akhter S H, Allen R, Ando S, Chisty E, Reisberg L and Vezzoli G 2008 The Paleogene record of Himalayan erosion: Bengal Basin, Bangladesh; Earth Planet. Sci. Lett. 273 1-14.

Nimis P 1999 Clinopyroxene geobarometry of magmatic rocks. Part 2. Structural geobarometers for basic to acid, tholeiitic and mildly alkaline magmatic systems; Contrib. Mineral. Petrol. 135 62-74.

Peng Z X and Mahoney J J 1995 Drillhole lavas in the Deccan Traps and the evolution of the Reunion plume; Earth Planet. Sci. Lett. 134 169-185.

Peng Z X, Mahoney J J, Hooper P R, Harris C and Beane J E 1994 A role for lower continental crust in flood basalt genesis? Isotopic and incompatible element study of the lower six formations of the Western Deccan Traps; Geochim. Cosmochim. Acta 58 267-288.

Peng Z X, Mahoney J J, Hooper P R, Macdougall J D and Krishnamurthy P 1998 Basalts of the northeastern Deccan Traps, India: Isotopic and elemental geochemistry and relation to southwestern Deccan stratigraphy; J. Geophys. Res. 103 29,843-29,865.

Roeder P L, Gofton E and Thornber C 2006 Cotectic proportions of olivine and spinel in olivine-tholeiitic basalt and evaluation of pre-eruptive processes; J. Petrol. 47 883-900.

Roeder P L and Schulze D J 2008 Crystallization of groundmass spinel in kimberlite; J. Petrol. 49 1473-1495.

Sen G, Bizimis M, Das R, Paul D K, Ray A and Biswas S 2009 Deccan plume, lithosphere rifting, and volcanism in Kutch, India; Earth Planet. Sci. Lett. 277 101-111, doi: 10.1016/j.epsl.2008.10.002.

Sheth H C 2005 From Deccan to Réunion: No trace of a mantle plume; Geol. Soc. Amer. Spec. Paper $\mathbf{3 8 8}$ $477-501$.

Sheth H C and Melluso L 2008 The Mount Pavagadh volcanic suite, Deccan Traps: Geochemical stratigraphy and magmatic evolution; J. Asian Earth Sci. 32 5-21.

Subbarao K V and Hooper P R 1988 Reconnaissance geological map of the Western Ghats; In: Deccan Flood Basalts; Subbarao K V (ed), Geol. Soc. India Memoir 10.

Wang C Y, Zhou M-F and Zhao D 2005 Mineral chemistry of chromite from the Permian Jinbaoshan Pt-Pd-sulphidebearing ultramafic intrusion in SW China with petrogenetic implications; Lithos 83 47-66.

Wang C Y, Zhou M-F and Zhao D 2008 Fe-Ti-Cr oxides from the Permian Xinjie mafic-ultramafic layered intrusion in the Emeishan large igneous province, SW China: Crystallization from $\mathrm{Fe}$ and Ti-rich basaltic magmas; Lithos 102 198-217.

Zhu B, Kidd W S F, Rowley D B and Currie B S 2004 Chemical compositions and tectonic significance of chrome-rich spinels in the Tianba Flysch, southern Tibet; J. Geol. 112 417-434. 